\title{
ATP-sensitive $\mathrm{K}^{+}$channels and insulin secretion: their role in health and disease
}

\author{
F. M. Ashcroft, F. M. Gribble \\ University Laboratory of Physiology, Oxford, UK
}

\section{Introduction}

Sulphonylureas have been used for over 50 years to enhance insulin secretion in patients with Type II (non-insulin-dependent) diabetes mellitus but their therapeutic target was not discovered until 1985 and we are only just beginning to address their molecular mechanism of action. The sulphonylurea drugs were discovered serendipitously by Marcel Janbon in 1942, when he observed a high incidence of hypoglycaemic symptoms in typhoid patients treated with the bacteriostatic agent $p$-aminobenzenesulphamidoisopropylthiodiazole (2254RP) [1]. This observation was extended by Auguste Loubatières, who showed that 2254RP induced hypoglycaemia in dogs by stimulating insulin secretion [2]. Subsequently, it was discovered that another sulphonamide drug being tested for bacteriostatic effects, carbutamide, also caused hypoglycaemia in man [3]. Clinical studies followed and led to the development of tolbutamide for the treatment of Type II diabetes. The full story of these pioneering experiments has been vividly recounted in an earlier review by Henquin [4]. Numerous sulphonylureas and related compounds have now been synthesized, with different potencies and time-courses of action and many millions of Type II diabetic patients are now routinely treated with these drugs.

The first clues to the mechanism of action of sulphonylureas on insulin secretion came with the dis-

Corresponding author: Prof. F. M. Ashcroft, University Laboratory of Physiology, Parks Road, Oxford OX1 3PT, UK

Abbreviations: $\mathrm{K}_{\mathrm{ATP}}$ channel, ATP-sensitive potassium channel; $\mathrm{PIP}_{2}$, phosphatidylinositol-4,5-bisphosphate; NBD, nucleotide-binding domain; TM, transmembrane domain; PHHI, persistent hyperinsulinaemic hypoglycaemia of infancy; MODY2, maturity-onset diabetes of the young, Type II; MIDD, maternally inherited diabetes with deafness; GLP1, glucagon-like peptide. covery that these drugs depolarize the pancreatic beta cell and stimulate electrical activity [5] and the finding that this depolarization was due to a decrease in the potassium permeability of the beta-cell membrane [6]. Patch-clamp studies subsequently showed that sulphonylureas interact specifically with the ATP-sensitive potassium $\left(\mathrm{K}_{\mathrm{ATP}}\right)$ channel in the betacell membrane and bring about its closure [7]. The activity of the $\mathrm{K}_{\mathrm{ATP}}$ channel sets the resting membrane potential of the unstimulated beta cell and its closure decreases the membrane $\mathrm{K}^{+}$permeability, producing membrane depolarization and insulin secretion [8]. Radioligand binding studies established the presence of both low-affinity and high-affinity sulphonylurea binding sites in the beta-cell membrane $[9,10]$ and led to considerable speculation about whether the high-affinity sulphonylurea receptor and the $\mathrm{K}_{\mathrm{ATP}}$ channel were the same or different proteins. The purification and subsequent cloning of a high-affinity sulphonylurea receptor from insulinoma cells [11] resolved this issue by showing that this receptor is an integral component of the $\mathrm{K}_{\mathrm{ATP}}$ channel $[12,13]$.

In this article, we review the role of the $\mathrm{K}_{\mathrm{ATP}}$ channel in insulin secretion in health and disease. We also summarise current knowledge of how sulphonylureas act on the different types of $\mathrm{K}_{\mathrm{ATP}}$ channel found in beta cells and in extra-pancreatic tissues, and discuss the implications of these findings for the use of sulphonylureas as therapeutic agents to stimulate insulin secretion in humans. Finally, we consider the evidence for additional targets for sulphonylureas, both within the beta cell and in extra-pancreatic tissues.

\section{Functional role of the $K_{\text {ATP }}$ channel in the pancreatic beta cell}

Insulin secretagogues can be divided into two groups: the initiators and the potentiators. The former are ca- 


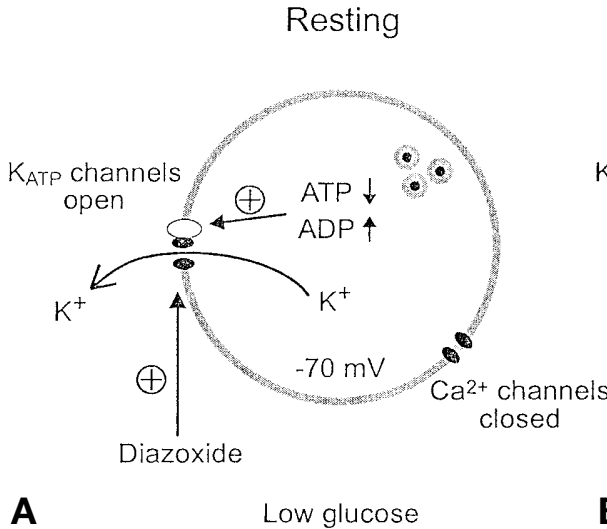

A

Low glucose

Fig. 1A, B. Model for insulin secretion. A resting. At low extracellular glucose levels $(<3 \mathrm{mmol} / \mathrm{l}), \mathrm{K}_{\mathrm{ATP}}$ channels are open and their activity sets the resting potential of the pancreatic beta-cell at a hyperpolarised level of approximately $-70 \mathrm{mV}$. Diazoxide opens the $\mathrm{K}_{\mathrm{ATP}}$ channel, which hyperpolarises the beta cell and inhibits insulin secretion, even in the presence of glucose. B active. Glucose metabolism, possibly by changes in intracellular adenine nucleotide concentrations, induces $\mathrm{K}_{\mathrm{ATP}}$ channel closure. This leads to membrane depolarization, opening of voltage-gated $\mathrm{Ca}^{2+}$ channels and an increase in cytosolic $\mathrm{Ca}^{2+}$ that triggers the exocytosis of insulin. Sulphonylureas block the $\mathrm{K}_{\text {ATP }}$ channel and initiate the same chain of events, even when glucose is absent

pable of stimulating insulin secretion on their own and include nutrients, such as glucose, and drugs such as the sulphonylureas. All these substances act by inhibiting $\mathrm{K}_{\mathrm{ATP}}$ channel activity but whereas the nutrients must be metabolised to effect channel closure, the drugs bind directly to the channel and block its activity. Potentiators of insulin secretion include a number of hormones [for example, glucagon and glucagon-like peptide (GLP1)], transmitters (such as acetylcholine) and the amino acid arginine. These agents amplify insulin secretion induced by an initiator but cannot elicit insulin secretion by themselves because they do not close $\mathrm{K}_{\mathrm{ATP}}$ channels and are only able to exert their effects after an initiator secretagogue has effected $\mathrm{K}_{\mathrm{ATP}}$ channel inhibition. Inhibition of insulin release is produced by agents that open $\mathrm{K}_{\text {ATP }}$ channels such as the drug diazoxide. Thus, the $\mathrm{K}_{\mathrm{ATP}}$ channel has a key role in the regulation of insulin secretion from the pancreatic beta cell [8].

Figure 1 illustrates the consensus model for stimulus-secretion coupling in the pancreatic beta cell. Insulin release is initiated by an increase of the intracellular $\mathrm{Ca}^{2+}$ concentration, which is mediated by $\mathrm{Ca}^{2+}$ influx through voltage-gated $\mathrm{Ca}^{2+}$ channels in the plasma membrane. The opening and closing (gating) of these $\mathrm{Ca}^{2+}$ channels is determined by the beta-cell membrane potential, which is in turn regulated by the activity of the $\mathrm{K}_{\mathrm{ATP}}$ channel. In the unstimulated
Active

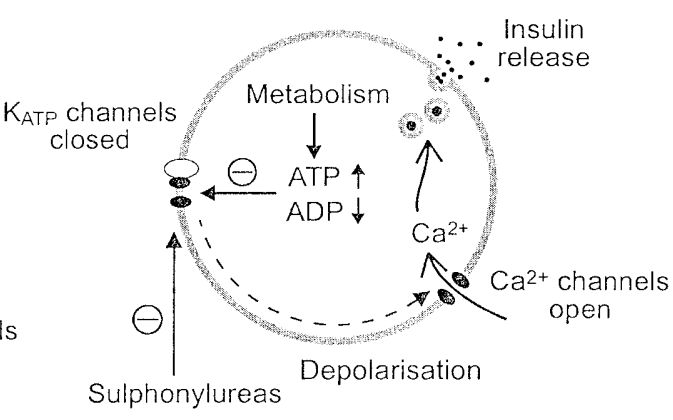

High glucose

beta cell, $\mathrm{K}_{\mathrm{ATP}}$ channels are open and the outward movement of $\mathrm{K}^{+}$ions through these channels holds the membrane potential at a negative level $(-70 \mathrm{mV})$, at which voltage-gated $\mathrm{Ca}^{2+}$ channels are closed. When the plasma glucose concentration rises, glucose uptake and metabolism by the pancreatic beta cell are enhanced and some product of glucose metabolism brings about the closure of the $\mathrm{K}_{\mathrm{ATP}}$ channels. This reduction in the membrane $\mathrm{K}^{+}$permeability causes the beta-cell membrane to depolarize (become less negative), because the outward flow of $\mathrm{K}^{+}$ ions is now smaller than the background inward current. As a consequence of the change in membrane potential, the voltage-gated $\mathrm{Ca}^{2+}$ channels open, allowing $\mathrm{Ca}^{2+}$ influx and stimulating insulin release. The product of glucose metabolism that regulates $\mathrm{K}_{\text {ATP }}$ channel activity remains controversial but, as discussed below, changes in the concentrations of adenine nucleotides may be involved.

Several classes of therapeutic drugs modulate insulin secretion by interacting directly with the $\mathrm{K}_{\mathrm{ATP}}$ channel $[10,14]$. The most important of these are the sulphonylureas, which are used to enhance insulin secretion in patients with Type II diabetes mellitus. These drugs act by inhibiting the $\mathrm{K}_{\mathrm{ATP}}$ channel, thereby depolarizing the beta cell and stimulating $\mathrm{Ca}^{2+}$ influx. In contrast to glucose, they interact directly with the channel to effect its closure. Another class of drugs are the K-channel openers. These comprise a structurally unrelated group of compounds that have the common property of opening $K_{\mathrm{ATP}}$ channels. This leads to hyperpolarization of the beta cell and prevents insulin release, even in the presence of glucose. The most potent $\mathrm{K}_{\mathrm{ATP}}$ channel opener in the beta cell is diazoxide. Although diazoxide is occasionally used to inhibit insulin secretion in patients with inoperable insulinoma or persistent hypoglycaemic hyperinsulinaemia of infancy (PHHI), it has adverse side-effects including hirsutism and lowering of blood pressure.

It is clear from Figure 1 that any reduction in $\mathrm{K}_{\text {ATP }}$ channel activity will enhance insulin secretion, whereas any increase in channel activity may be expected to decrease insulin release. It is therefore not surpri- 
sing that mutations in the $\mathrm{K}_{\text {ATP }}$ channel which abolish or appreciably reduce its activity, result in the human disease PHHI, which is characterised by persistent insulin secretion in the face of very low blood glucose concentrations. In contrast, mutations in genes that compromise beta-cell metabolism and impair the ability of glucose to close the $\mathrm{K}_{\mathrm{ATP}}$ channel lead to certain forms of diabetes (MODY2 and MIDD). These diseases are discussed more fully below.

Metabolic regulation of the $K_{A T P}$ channel. The defining characteristic of the $\mathrm{K}_{\mathrm{ATP}}$ channel is that its activity is inhibited by an increase in the intracellular ATP concentration. When measured in inside-out membrane patches, the channel is highly ATP-sensitive, being half-blocked by approximately $10 \mu \mathrm{mol}$ ATP $[15,16]$. By contrast, estimates of the ATP-sensitivity of the channel in the intact beta cell suggest a $K_{i}$ of approximately $1-2 \mathrm{mmol} / \mathrm{l}[17,18]$. The fact that significant $\mathrm{K}_{\mathrm{ATP}}$ channel activity is observed in cell-attached patches on beta cells exposed to glucose-free solutions [19], where intracellular ATP concentrations are thought to lie in the millimolar range [20-22], is also consistent with the view that the ATP-sensitivity of the $\mathrm{K}_{\mathrm{ATP}}$ channel is lower in the intact cell than is found in the excised patch. This paradox is explained by the presence of intracellular agents that reduce the ATP-sensitivity of the $\mathrm{K}_{\mathrm{ATP}}$ channel in the intact cell but are washed away from the membrane when the patch is excised.

Several cytosolic agents are known to modulate the ATP-sensitivity of the $\mathrm{K}_{\text {ATP }}$ channel, including $\mathrm{Mg}$ nucleotides [23, 24], oleoyl CoA [25-28] (a metabolic intermediate) and the membrane phospholipid phosphatidylinositol-4,5-bisphosphate $\left(\mathrm{PIP}_{2}\right)$ [29-31]. The relative contributions of these effects remain to be established. The effect of $\mathrm{PIP}_{2}$ on the ATP-sensitivity of the $\mathrm{K}_{\mathrm{ATP}}$ channel, however, is particularly dramatic and intracellular application of $5 \mu \mathrm{mol} / 1$ $\mathrm{PIP}_{2}$ can reduce the half-maximum inhibitory concentration of ATP from approximately $10 \mu \mathrm{mol} / 1$ to more than $3 \mathrm{mmol} / \mathrm{l}$ within a few minutes [30]. The greater ATP-sensitivity observed in isolated membrane patches might therefore be explained by gradual washout of PIP ${ }_{2}$ from the cell membrane following patch excision. It seems possible that the concentration of $\mathrm{PIP}_{2}$ sets the resting ATP-sensitivity of the channel and accounts for the difference between the ATP-sensitivity observed in the excised patch and the intact cell. Whether or not changes in $\mathrm{PIP}_{2}$ concentration contribute to the metabolic regulation of $\mathrm{K}_{\text {ATP }}$ channel activity is still unclear.

The long-chain acyl-CoA ester, oleoyl CoA, is also able to activate $K_{\text {ATP }}$ channels [25-27] and reduce their sensitivity to ATP [28]. A threefold shift in ATP-sensitivity was found with $1 \mu \mathrm{mol} / 1$ oleoyl CoA. The relative potency of oleoyl CoA and $\mathrm{PIP}_{2}$ is difficult to ascertain because the membrane concentra- tion of the lipid will depend on its lipophilicity and on the duration of application. Their contributions to the resting ATP-sensitivity of the $\mathrm{K}_{\mathrm{ATP}}$ channel also remain to be established. Long-term exposure to non-esterified fatty acids (NEFAs), which occurs in obese subjects $[32,33]$ increases intracellular concentrations of LC acyl-CoA esters in the beta cell $[25,34]$. This would be expected to activate $\mathrm{K}_{\text {ATP }}$ channels, thereby tending to hyperpolarize the beta cell and inhibit insulin secretion. Thus it is possible that increased $\mathrm{K}_{\mathrm{ATP}}$ channel activity, induced by long-chain acyl-CoA esters, contributes to the impaired insulin secretion observed in obese Type II diabetic patients.

Mg-nucleotides, such as MgADP, also enhance $\mathrm{K}_{\text {ATP }}$ channel activity and decrease its sensitivity to ATP [23, 24]. Nucleotide diphosphates such as $\mathrm{MgADP}$ and $\mathrm{MgGDP}$ are more potent in this respect than nucleotide triphosphates [35, 36]. Because ADP and ATP change reciprocally when glucose is metabolised, it was argued some time ago that changes in MgADP might contribute to the metabolic regulation of the channel [23, 24]. Recent studies of the cloned $\mathrm{K}_{\mathrm{ATP}}$ channel support this view. These have shown that mutations which abolish the ability of MgADP to activate the $\mathrm{K}_{\mathrm{ATP}}$ channel, also lead to the loss of metabolic regulation when the mutant channels are expressed in mammalian cells or Xenopus oocytes [37-39].

\section{$K_{\text {ATP }}$ channels in other tissues}

$\mathrm{K}_{\mathrm{ATP}}$ channels are not only found in pancreatic betacells. They were first described in cardiac muscle [40] and then in beta cells [15] and subsequently have been found in a wide variety of other tissues, including smooth and skeletal muscle, brain neurones, peripheral axons and epithelial cells [10]. In all these tissues, they couple cell metabolism to membrane excitability and in some cases they mediate the actions of hormones and transmitters. In cardiac muscle they are involved in action potential shortening during ischaemia [41], in vascular smooth muscle they regulate vessel tone [42] and in skeletal muscle they contribute to the enhanced $\mathrm{K}^{+}$efflux and fatigue found during severe exercise [43]. Their physiological role in neurones is not clearly established but it is believed that they regulate synaptic transmitter release [44] and that they might be involved in the response to cerebral ischaemia [45].

$\mathrm{K}_{\text {ATP }}$ channels in different tissues exhibit considerable variability in their sensitivity to K-channel openers [14, 46-48]. The beta-cell channel is activated by diazoxide, slightly activated by pinacidil and unaffected by cromakalim, nicorandil or minoxidil; cardiac and skeletal muscle $\mathrm{K}_{\text {ATP }}$ channels are activated by pinacidil, cromakalim and nicorandil but not by di- 


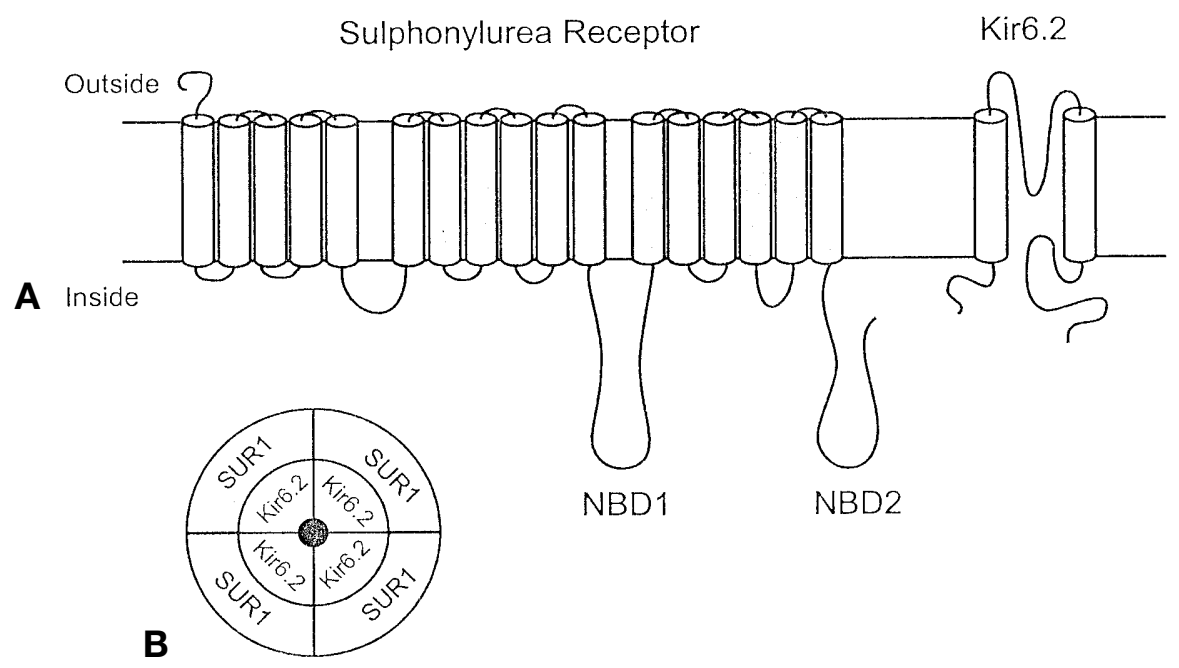

Fig. 2A, B. The $\mathrm{K}_{\mathrm{ATP}}$ channel is composed of two types of subunits, Kir 6.2, and SUR. $\mathrm{K}_{\text {ATP }}$ channel topology. A Hydropathy analysis suggests that Kir6.2 (right) has two transmembrane domains whereas SUR1 (left) has multiple transmembrane domains and two cytosolic nucleotide binding domains (NBDs), each of which contains a Walker $\mathrm{A}\left(\mathrm{W}_{\mathrm{A}}\right)$ and a Walker $\mathrm{B}$ $\left(\mathrm{W}_{\mathrm{B}}\right)$ motif. These motifs are involved in the activation of the $\mathrm{K}_{\mathrm{ATP}}$ channel by MgADP. The predicted molecular weight of Kir 6.2 is $43 \mathrm{kDa}[12,13]$ and that of SUR1 is $177 \mathrm{kDa}[11]$. B The $\mathrm{K}_{\text {ATP }}$ channel is an octameric complex of four poreforming Kir6.2 subunits and four regulatory sulphonylurea receptor subunits

azoxide; and smooth muscle $\mathrm{K}_{\mathrm{ATP}}$ channels are activated by diazoxide, cromakalim, pinacidil and nicorandil. Some differences have also been reported in the tissue specificity of sulphonylureas, as discussed more fully below.

The macroscopic (whole-cell) $\mathrm{K}_{\mathrm{ATP}}$ current is determined by the product of the number of channels in the cell membrane, the single-channel current and the percentage of time the channel stays open (the open probability). The single-channel conductance of both cardiac and beta-cell $\mathrm{K}_{\mathrm{ATP}}$ channels in symmetrical $140 \mathrm{mmol} / 1 \mathrm{~K}^{+}$solutions lies between 55-80pS, depending on the temperature at which the recordings are made $[8,16,40,41,143]$. In smooth muscle, the reported single-channel conductance varies widely, suggesting that there might be more than one type of $\mathrm{K}_{\mathrm{ATP}}$ channel in this tissue [42]. Sulphonylureas and K-channel openers modulate the whole-cell current by influencing the channel open probability rather than the single-channel conductance.

A key question is to what extent $\mathrm{K}_{\mathrm{ATP}}$ channels are open under physiological conditions in tissues other than the beta cell, as this will determine whether or not sulphonylureas will have functional effects on extra-pancreatic tissues. In cardiac muscle, it is fairly clear that $\mathrm{K}_{\mathrm{ATP}}$ channels are normally closed and open only under conditions of severe metabolic stress [41]. In other tissues, however, their resting level of activity remains to be established. Another issue is whether the different metabolic sensitivities observed for cardiac and beta-cell $\mathrm{K}_{\mathrm{ATP}}$ channels result from differences in the metabolism of these tissues or are in the properties of the channels themselves.

\section{Molecular identity of the $K_{\text {ATP }}$ channel}

The $\mathrm{K}_{\text {ATP }}$ channel is formed from two types of subunit: a pore-forming subunit, Kir6.x and a regulatory subunit, the sulphonylurea receptor (SUR), which coassembles with a 4:4 stoichiometry [49-51]. Two different Kir6.x genes have been described, Kir6.1 and Kir6.2 [12, 13, 52]. Likewise, two genes encoding sulphonylurea receptors, SUR1 and SUR2, have been cloned and further diversity is created by alternative splicing of $S U R 2$ [11, 53-55]. Coexpression of Kir6. 2 with SUR1 in both mammalian cells and in $X e$ nopus oocytes results in $\mathrm{K}_{\mathrm{ATP}}$ currents with properties identical to those of the native beta-cell $\mathrm{K}_{\mathrm{ATP}}$ channel $[12,13,56]$.

Kir6.2 is a member of the inwardly rectifying $\mathrm{K}^{+}$channel family and, like other members of this family [57], has two transmembrane domains (TMs), linked by a pore loop and cytosolic amino and carboxy termini (Fig. 2). There is no obvious consensus sequence for ATP-binding, although recent studies suggest that ATP interacts with this subunit to close the channel $[58,59]$. The sulphonylurea receptors belong to the ABC-transporter superfamily [11], which includes the cystic fibrosis gene product (CFTR) and the multidrug-resistance $p$-glycoprotein. These proteins are characterised by multiple transmembrane domains and two intracellular nucleotide-binding domains (NBDs) which contain consensus sequences for nucleotide binding and hydrolysis [60, 61] (Fig. 2). SUR is thought to possess $17 \mathrm{TMs}$ arranged in three groups of $5+6+6[62,63]$. 
Electrophysiological studies have shown that different combinations of Kir and SUR subunits account for the diverse properties of $\mathrm{K}_{\mathrm{ATP}}$ channels in different tissues. Kir6.2 is strongly expressed in beta cells, heart, brain and skeletal muscle and is likely to form the pore of the $\mathrm{K}_{\text {ATP }}$ channel in all these tissues $[12,13]$. Both Kir6.1 and Kir6.2 have been postulated to serve as the pore of the smooth muscle $\mathrm{K}_{\mathrm{ATP}}$ channel $[53,64]$ and it seems possible that both suggestions may be correct and that Kir6.1 and Kir6.2 form ATP-sensitive $\mathrm{K}^{+}$channels with different properties [145]. There is evidence that SUR1 serves as the regulatory subunit of the $\mathrm{K}_{\mathrm{ATP}}$ channel in beta cells and some types of neurones [11, 12, 65, 66], SUR2A in cardiac and skeletal muscle $[54,55]$ and SUR2B in smooth muscle [53, 64].

In contrast to most other members of the Kir channel family, Kir6.2 does not form functional channels in the absence of the sulphonylurea receptor $[12,13]$. Fortuitously, it was discovered that removal of the last 26 or 36 amino acids from the C-terminus of Kir6.2 (Kir6.2 $\Delta$ C36) allows the independent functional expression of this subunit [58]. This is because truncation of the C-terminus deletes a retention signal that (in the absence of SUR) prevents the trafficking of Kir6.2 to the plasma membrane [67]. Thus, one function of SUR is as a chaperone protein, to facilitate the surface expression of Kir6.2: there is also some evidence that Kir6.2 provides a reciprocal service for SUR [49]. The C-terminally truncated Kir6.2 has proved a useful experimental tool for addressing the properties of the $\mathrm{K}_{\mathrm{ATP}}$ channel.

Mutagenesis studies address the relation between $K_{A T P}$ channel structure and function. The question of which $\mathrm{K}_{\mathrm{ATP}}$ channel properties are endowed by Kir6.2 and which by SUR has been resolved by three types of experiments [68]. First, and most unequivocally, by the use of truncated forms of Kir6.2 which enable this subunit to form functional channels in the absence of a sulphonylurea receptor; secondly, by examining the properties of $\mathrm{K}_{\mathrm{ATP}}$ channels composed of different types of SUR subunit; and thirdly, by making site-directed mutations in either Kir6.2 or SUR.

Such studies have shown that the pore of the $\mathrm{K}_{\text {ATP }}$ channel is formed from Kir6.2 subunits and that SUR does not influence the single-channel conductance or ion selectivity. To many people's surprise, Kir6.2 was also found to contain the primary site at which ATP acts to cause $\mathrm{K}_{\mathrm{ATP}}$ channel inhibition. This subunit is sensitive to ATP when expressed alone [58, 69, 70], shows reduced ATP-sensitivity when it is mutated [58,71-73] and can be photo-affinity labelled with 8 -azido- $\left.{ }^{32} \mathrm{P}\right]$ ATP [59]. The location of the binding site for ATP on Kir6. 2 continues to remain elusive. It differs from most classical ATP-binding sites in that nucleotide binding does not require $\mathrm{Mg}^{2+}$ [74]; that the affinity for ADP is almost as high as that for ATP [71]; and that it is highly selective for the adenine moiety (GTP, ITP, etc. are poor channel blockers) [71]. Thus it may constitute a novel class of ATP-binding site.

It is thought that both oleoyl CoA and $\mathrm{PIP}_{2}$ reduce the ATP-sensitivity of the $\mathrm{K}_{\text {ATP }}$ channel by interaction with Kir6.2, since both agents are effective when this subunit is expressed in the absence of SUR [28, 29]. Two mechanisms have been put forward to explain this effect. First, $\mathrm{PIP}_{2}$ and ATP might compete for the same, or overlapping, binding sites on Kir6.2. Secondly, the presence of negatively charged phospholipid in the membrane might reduce the local concentration of the negatively charged ATP molecule by electrostatic effects and thus cause an apparent reduction in ATP-affinity. Much work is currently devoted to resolving whether one, or both, of these explanations is correct.

The sulphonylurea receptor is very important for metabolic regulation of the $\mathrm{K}_{\mathrm{ATP}}$ channel as it confers sensitivity to the stimulatory effects of MgADP and MgGDP [35-39]. The effects of these nucleotides are mediated through interaction with the nucleotide-binding domains (NBDs) of SUR. The details of the mechanism have not yet been worked out but it seems that both NBDs are involved because mutation of a single NBD is sufficient to abolish the stimulatory effect of MgADP. This is consistent with functional studies of bacterial and eukaryotic ABC transporters $[60,75]$. Nucleotide activation is dependent on the presence of $\mathrm{Mg}^{2+}$, does not discriminate between adenine, guanine or uridine nucleotides and $\mathrm{MgADP}$ is a more effective agonist than MgATP $[36,39]$. In all these respects, the nucleotide-binding site of SUR differs from the ATP-binding site on Kir6.2.

Mutations in the NBDs that abolish the stimulatory effects of $\mathrm{Mg}$-nucleotides also prevent $\mathrm{K}_{\mathrm{ATP}}$ channel activation by metabolic inhibition in intact cells $[37,38]$. This argues that the SUR subunit, and its NBDs in particular, are critical for the metabolic regulation of the $\mathrm{K}_{\mathrm{ATP}}$ channel. It is perhaps worth emphasizing that these studies show that a key physiological role of SUR is to mediate the metabolic regulation of channel activity; it might be simply providential that SUR also binds sulphonylureas.

In summary, studies of cloned channels confirm that, as previously suspected [76, 77], MgADP interacts with the $\mathrm{K}_{\mathrm{ATP}}$ channel at two sites, one that induces channel inhibition (now known to be on Kir6.2) and one that causes channel activation (on SUR). The overall action of MgADP, therefore, will be a balance between these two effects. Because ATP also interacts with both stimulatory and inhibitory sites $[36,58]$, it is not a simple matter to work out the relative contributions of the adenine nucleotides to $\mathrm{K}_{\mathrm{ATP}}$ channel regulation in the intact beta cell. 
In addition to mediating the stimulatory effects of MgADP, SUR endows the $\mathrm{K}_{\text {ATP }}$ channel with several other properties. One finding is that SUR enhances the channel ATP-sensitivity, decreasing the $K_{i}$ for ATP inhibition of Kir6.2 from approximately $100 \mu \mathrm{mol} / 1$ to that found for the wild-type channel $(\sim 10 \mu \mathrm{mol} / \mathrm{l})$ [58]. The mechanism involved has not yet been elucidated. The sulphonylurea receptor is also the principal target for pharmacological agents and confers high sensitivity both to sulphonylureas and to $\mathrm{K}^{+}$channel openers on Kir6.2. The mechanism of sulphonylurea action is discussed in more detail below: in this review, we do not consider how K-channel openers work because their molecular mechanism of action is less well understood.

\section{Sulphonylurea action}

The sulphonylurea receptor, as its name suggests, is the primary target for sulphonylureas. High-affinity binding sites for sulphonylureas were first identified in studies on rat brain and beta-cell tumours in the early 1980 s. Subsequently, extensive studies were carried out to characterise the properties of the binding sites for sulphonylureas in membranes isolated from beta cells, cardiac and smooth muscle. These studies (reviewed by [10]), showed the presence of both high-affinity and low-affinity sites for sulphonylureas. The high-affinity beta-cell sulphonylurea receptor (SUR1) was purified and subsequently cloned by Aguilar-Bryan and her colleagues in a landmark paper published in 1995 [11]. The relative affinity of SUR1 for different sulphonylureas was identical to that found in native beta-cells [10], with glibenclamide being much more potent than tolbutamide. Related sulphonylurea receptors were later cloned from heart (SUR2A), brain and smooth muscle (SUR2B) [53-55]. The cloned receptor SUR2A exhibits lower affinity for glibenclamide than SUR1 in binding studies, although both show approximately the same affinity in electrophysiological studies. Possible reasons for this difference are discussed below.

In addition to sulphonylureas, $\mathrm{K}_{\mathrm{ATP}}$ channels are blocked by a variety of benzoic acid derivatives (e.g. meglitinide) and by $N$-acylphenylalanine derivatives, such as A4166, which explains the ability of these compounds to enhance insulin secretion [78-80]. These drugs also interact with SUR1. The formulae of some of these non-sulphonylurea compounds, and of some of the most widely used sulphonylureas are given in Figure 3.

How do sulphonylureas inhibit the $K_{A T P}$ channel? Studies of native beta-cell $\mathrm{K}_{\mathrm{ATP}}$ channels established that sulphonylureas inhibit the macroscopic (wholecell) $\mathrm{K}_{\mathrm{ATP}}$ current by reducing the channel open probability and that they have no effect on the sin-

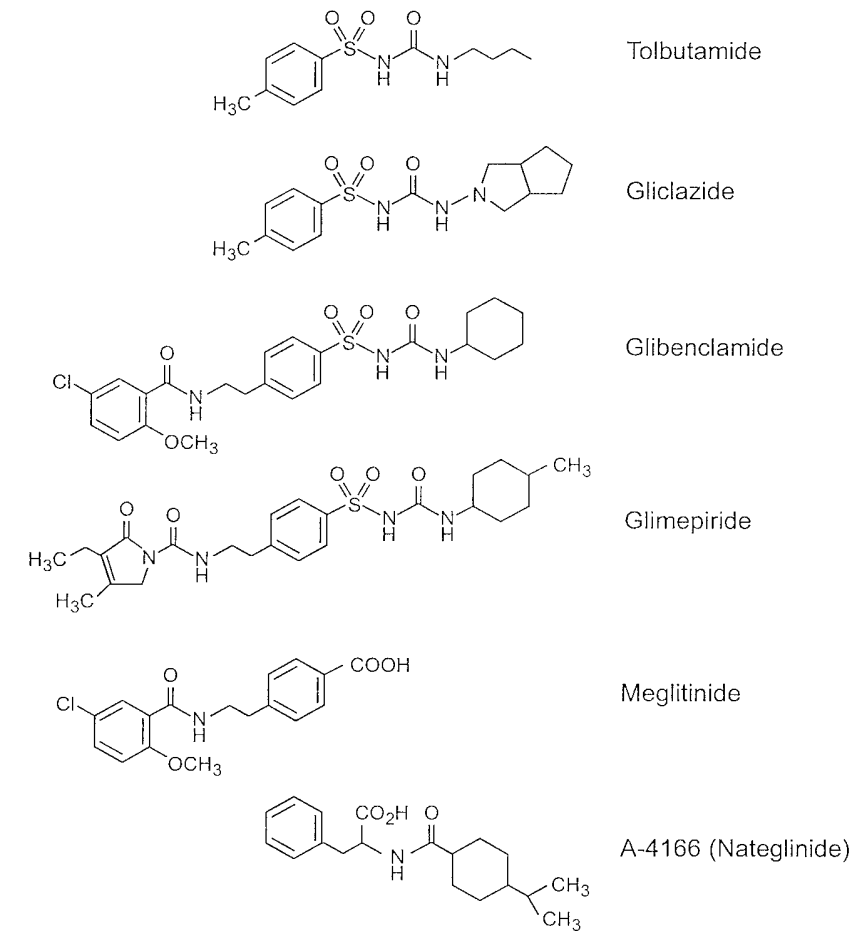

Fig. 3. Chemical structures of tolbutamide, gliclazide, glibenclamide, glimperide, meglitinide and A4166

gle-channel conductance [97]. More recent studies of cloned $\mathrm{K}_{\mathrm{ATP}}$ channels have shed further light on the mechanism of action of sulphonylureas [81, 82]. It has become clear that these drugs interact with the $\mathrm{K}_{\mathrm{ATP}}$ channel at two sites: a low-affinity site that lies on Kir6.2 and a high-affinity site located on SUR1. Figure 4 illustrates the relation between tolbutamide concentration and inhibition of the cloned beta-cell type of $\mathrm{K}_{\mathrm{ATP}}$ channel (Kir6.2/SUR1) measured in the giant inside-out patch. This is best fit by a two-site model with an $\mathrm{EC}_{50}$ of $2 \mu \mathrm{mol} / 1$ for the high-affinity site and of $2 \mathrm{mmol} / \mathrm{l}$ for the low-affinity site. For reasons that remain unclear, high-affinity inhibition blocks only about $60 \%$ of the total current. One plausible explanation for this unexpected finding is that the $\mathrm{K}_{\text {ATP }}$ channel exists in two states, only one of which is susceptible to tolbutamide inhibition. The picture is different in intact cells, where saturation of the high-affinity site does produce complete block of the channel. The reason this is the case is discussed more fully later.

The identity of the low-affinity sulphonylurea site was investigated by expressing a C-terminally truncated Kir6.2 (Kir6.2 $\Delta$ C36) in the absence of the sulphonylurea receptor [81]. Inhibition of Kir6.2 $\Delta \mathrm{C} 36$ currents by sulphonylureas was found to be mediated by a single low-affinity site, with a $K_{i}$ of $1.7 \mathrm{mmol} / \mathrm{l}$ for tolbutamide and of $42 \mu \mathrm{mol} / \mathrm{l}$ for glibenclamide (Fig. 4) [82]. These values are the same as those obtained for the low-affinity site observed when Kir6.2 is coexpressed with SUR, confirming that the low-af- 
Kir6.2 + SUR1

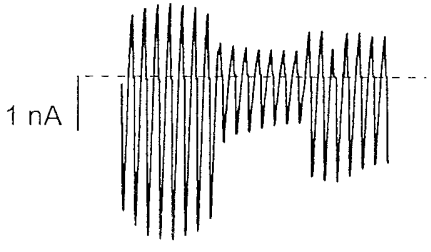

A

$100 \mu \mathrm{mol} / / \mathrm{l}$ tolbutamide
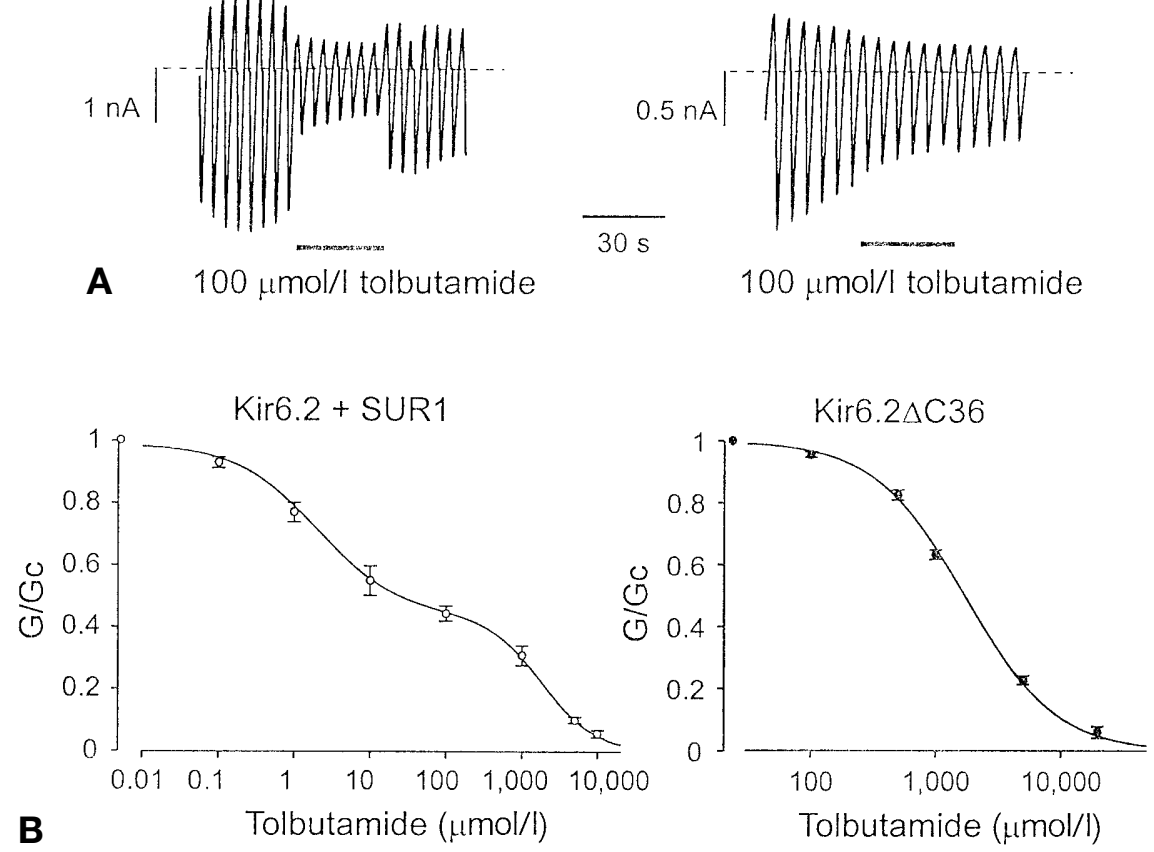

Fig.4A, B. Tolbutamide interacts with two sites on the betacell $\mathrm{K}_{\mathrm{ATP}}$ channel, a high-affinity site on SUR1 and a low-affinity site of Kir6.2. A Effect of tolbutamide $(0.1 \mathrm{mmol} / \mathrm{l})$ on the beta-cell $\mathrm{K}_{\mathrm{ATP}}$ channel (Kir6.2/SUR1, left), and on the truncated Kir6.2 subunit (Kir6.2 $\Delta$ C36) expressed in the absence of SUR (right) The decline in current amplitude observed in control solution is a characteristic feature of native and cloned $\mathrm{K}_{\text {ATP }}$ channels. It is initiated following patch excision and the rate is very variable. The mechanism of channel rundown is still unclear but it is thought to reflect the time-dependent loss from the patch membrane of a substance that promotes channel activity. B Concentration-response relation for tolbutamide block of Kir6.2/SUR1 (left) and Kir6.2 $\Delta$ C36 (right) currents. The conductance in the presence of the sulphonylurea is expressed as a fraction of that in the absence of the drug. Xenopus oocytes were coinjected with mRNAs encoding either Kir6.2 plus SUR1, or Kir6.2AC36, and macroscopic currents were recorded from inside-out patches in response to a series of voltage ramps from $-110 \mathrm{mV}$ to $+100 \mathrm{mV}$. The data are taken from from ref [81]

finity site resides on Kir6.2 and the high-affinity site on SUR1. The low-affinity site on Kir6.2 might not be the same as that identified in binding studies on native membranes, which could be associated with a different protein. Low-affinity block is unlikely to be of clinical relevance because plasma concentrations in diabetic patients do not reach such levels [83, 84]. The dose-response curves for sulphonylureas can, however, only be correctly interpreted when the lowaffinity block is taken into account.

Given that the $\mathrm{K}_{\text {ATP }}$ channel is an octamer, containing 4 SUR subunits, the question arises as to the number of sulphonylurea molecules required to block the channel. This question remains to be answered.

Specificity of sulphonylurea action. A number of studies suggest that the different types of $\mathrm{K}_{\text {ATP }}$ channel exhibit different specificities towards the various sulphonylureas. In particular, tolbutamide inhibits the beta cell (Kir6.2/SUR1) but not the cardiac (Kir6.2/ SUR2A) type of $\mathrm{K}_{\text {ATP }}$ channel with high affinity (Fig.5). The low tolbutamide sensitivity of Kir6.2/ SUR2A currents is consistent with that reported for native cardiac $\mathrm{K}_{\mathrm{ATP}}$ channels $\left(K_{i} \sim 1 \mathrm{mmol} / 1\right.$; ref [85, $143])$ and is similar to that found when Kir6.2 $\Delta C 36$ is expressed in the absence of a sulphonylurea receptor $\left(K_{i} \sim 2 \mathrm{mmol} / \mathrm{l}\right)$ [81]. Thus it appears that SUR2A, unlike SUR1, does not confer high-affinity tolbutamide inhibition on the $\mathrm{K}_{\text {АTP }}$ channel. Gliclazide also appears to interact specifically with the beta-cell type of sulphonylurea receptor and not with that found in heart or smooth muscle [86]. Its affinity is greater than that of tolbutamide $\left(K_{i}=50\right.$ $\mathrm{nmol} / \mathrm{l}$ for gliclazide and $\sim 2 \mu \mathrm{mol} / \mathrm{l}$ for tolbutamide).

In contrast to tolbutamide, glibenclamide blocks both beta-cell and cardiac $\mathrm{K}_{\text {ATP }}$ channels with high affinity (Fig.5). The $K_{i}$ s for Kir6.2/SUR1 and Kir6.2/ SUR2A currents were approximately $4 \mathrm{nmol} / \mathrm{l}$ and approximately $27 \mathrm{nmol} / \mathrm{l}$, respectively [82]. Similar affinities are reported for native channels: the $K_{i}$ of the beta-cell channel is $4 \mathrm{nmol} / \mathrm{l}$ [87], that of skeletal muscle is $6 \mathrm{nmol} / 1$ [48] and that of cardiac muscle is 7 $\mathrm{nmol} / 1[88,89]$. One important difference, however, is that glibenclamide block of cardiac $\mathrm{K}_{\mathrm{ATP}}$ channels is readily reversible but inhibition of beta-cell $\mathrm{K}_{\mathrm{ATP}}$ channels is not reversible on the time scale of electro- 

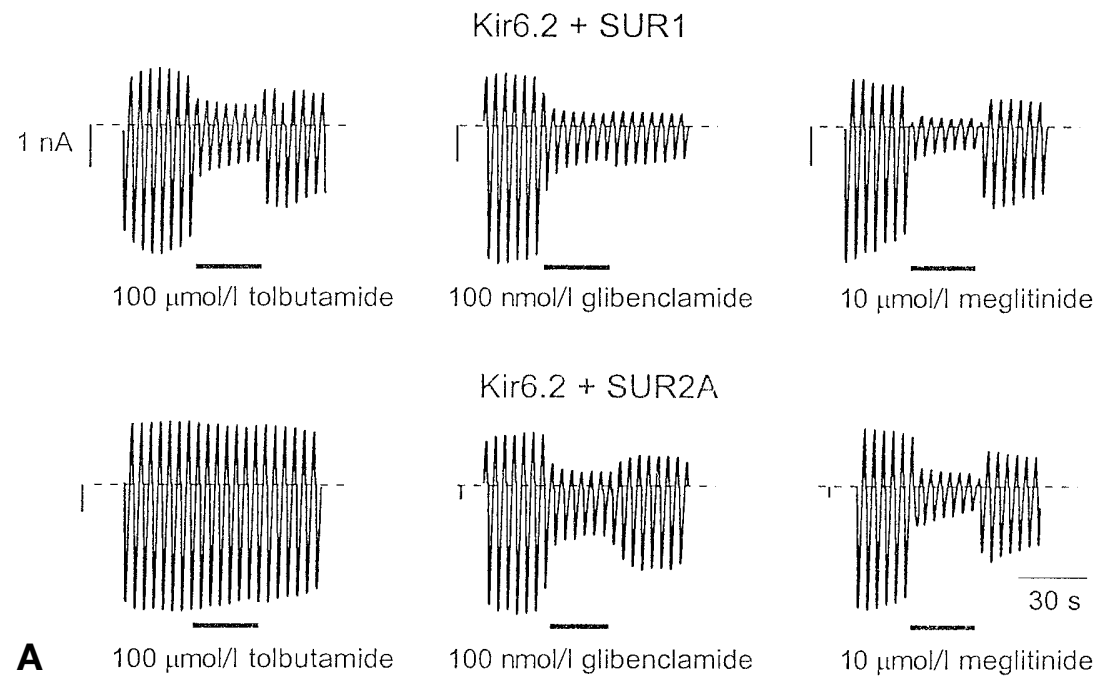

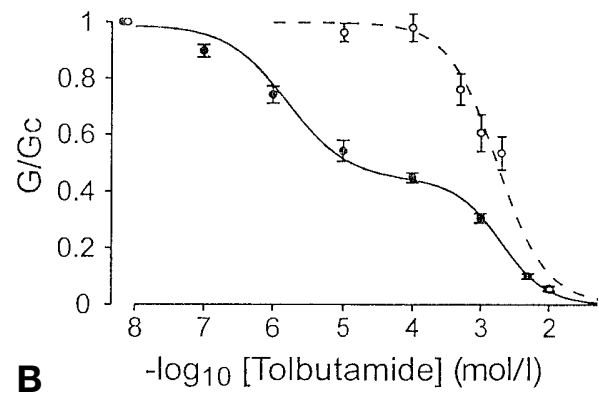

Fig. 5 A-C. Tolbutamide blocks beta-cell but not cardiac $\mathrm{K}_{\mathrm{ATP}}$ channels with high-affinity whereas glibenclamide blocks both types of channel. A Effects of tolbutamide $(0.1 \mathrm{mmol} / \mathrm{l})$, glibenclamide $(100 \mathrm{nmol} / \mathrm{l})$ or meglitinide $(10 \mu \mathrm{mol} / \mathrm{l})$ on cloned beta cell (Kir6.2/SUR1) and cardiac (Kir6.2/SUR2A) $\mathrm{K}_{\text {ATP }}$ channel currents. From ref [82]. B, C Concentration-response relations for tolbutamide $(\mathbf{B})$ and glibenclamide $(\mathbf{C})$ inhibition of Kir6.2/SUR1 and Kir6.2/SUR2A currents. The conductance in the presence of the sulphonylurea is expressed as a fraction of that in the absence of the drug. Oocytes were coinjected with mRNAs encoding Kir6.2 and either SUR1 or SUR2A, and macroscopic currents recorded from inside out patches in response to a series of voltage ramps from $-110 \mathrm{mV}$ to $+100 \mathrm{mV}$. From ref [82]. -O- Kir6.2 + SUR1, - - - Kir6.2 + SUR2A

physiological experiments [82], consistent with the slow dissociation rate of the drug in $\left[{ }^{3} \mathrm{H}\right]$-glibenclamide binding studies [90]. This slow dissociation may contribute to the long washout time observed when glibenclamide therapy is discontinued in patients.

Meglitinide is not a sulphonylurea but is a benzamido derivative, equivalent to the non-sulphonylurea moiety of glibenclamide (Fig. 3). Like glibenclamide, meglitinide mediates high-affinity inhibition of native beta-cell $\mathrm{K}_{\mathrm{ATP}}$ channels and of both the cloned betacell and cardiac $\mathrm{K}_{\mathrm{ATP}}$ channel [78, 82, 87]. The affinity of this block is similar for the beta-cell and car-

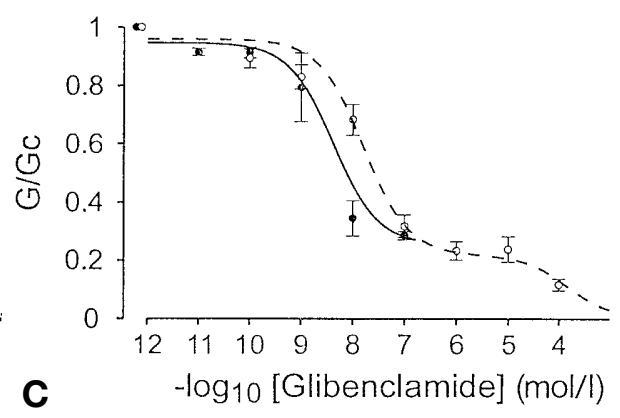

diac types of $\mathrm{K}_{\mathrm{ATP}}$ channel $\left(K_{i} \mathrm{~s} \sim 0.3 \mu \mathrm{mol} / 1\right.$ and $\sim 0.5 \mu \mathrm{mol} / 1$, for Kir6.2/SUR1 and Kir6.2/SUR2A channels, respectively) and in both cases is readily reversible $[82,87]$. These results have been interpreted to indicate that both SUR1 and SUR2A may possess a benzamido-binding site.

There are several possible explanations for why tolbutamide does not inhibit SUR2A currents with high affinity. Firstly, SUR2A may not possess a highaffinity tolbutamide binding site. Secondly, tolbutamide may bind to SUR2A with high-affinity but this binding may not result in channel closure. Current evidence favours the idea that although both SUR1 and SUR2A possess a 'benzamido'-binding site, only SUR1 possesses a 'sulphonylurea'-binding site (Fig. 6) [82]. Because glibenclamide contains both sulphonylurea and meglitinide moieties, it seems plausible that this drug binds to SUR1 at both the sulphonylurea and benzamido sites, but only interacts with a single (benzamido) site on SUR2A. This might account for the irreversible inhibition of Kir6.2/ SUR1 currents by glibenclamide, since simultaneous unbinding from both the sulphonylurea and benzamido sites is likely to occur with a low probability. By contrast, glibenclamide unbinding from SUR2A would occur more rapidly, since the drug need only dissociate from a single site. Likewise, tolbutamide and meglitinide, which also only interact with a single 

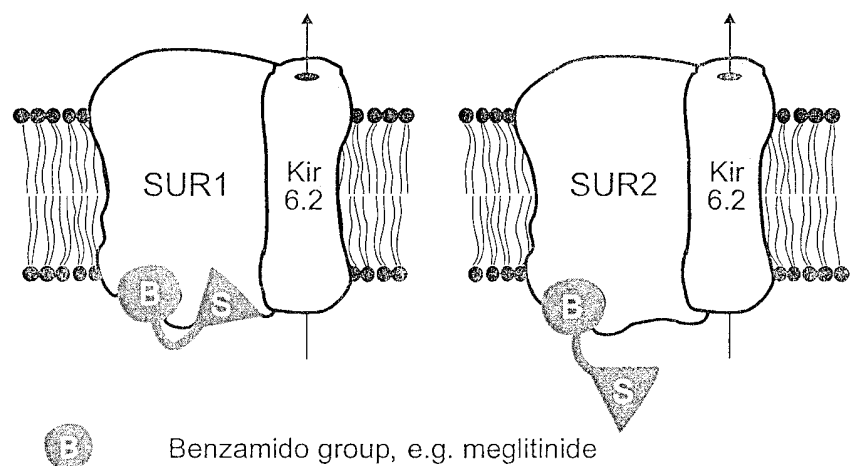

Benzamido group, e.g. meglitinide

Sulphonylurea group, e.g. gliclazide, tolbutamide

Both groups, e.g. glibenclamide

Fig. 6. Model for glibenclamide interaction with beta-cell and cardiac $\mathrm{K}_{\mathrm{ATP}}$ channels. $\mathrm{K}_{\mathrm{ATP}}$ channels containing the beta-cell sulphonylurea receptor, SUR1, have high-affinity sites for both sulphonylureas and benzamido compounds, whereas those containing the cardiac sulphonylurea receptor, SUR2A, have only the benzamido site. Because glibenclamide possesses both sulphonylureas and benzamido moieties it interacts with SUR1 at two sites, but only with a single site on SUR2A. Consequently, drug inhibition of Kir6.2/SUR1 currents reverses more slowly

site, are readily reversible on both beta-cell and cardiac types of $\mathrm{K}_{\mathrm{ATP}}$ current. It is notable that earlier studies, carried out before the isolation of SUR, also led to the speculation that second generation sulphonylureas like glibenclamide interact with two sites in the beta-cell membrane [78, 91, 92].

Although similar studies have not yet been carried out to determine the specificity of other types of sulphonylurea, we suggest that drugs that show structural similarities to either glibenclamide or meglitinide may be expected to interact with both SUR1 and SUR2 whereas those that resemble tolbutamide and gliclazide in structure may interact specifically with SUR1.

Interaction between sulphonylureas and $M g A D P$. Studies on native beta cells first showed a clear discrepancy between the inhibitory effect of sulphonylureas on whole-cell $\mathrm{K}_{\mathrm{ATP}}$ currents and those observed in excised membrane patches. Whereas $1 \mathrm{mmol} / \mathrm{l}$ tolbutamide was able to fully block the whole-cell current, complete inhibition was never observed in the excised patch $[87,97]$. A similar anomaly is found for sulphonylurea inhibition of cloned beta-cell $\mathrm{K}_{\mathrm{ATP}}$ channels $[56,81]$. Further analysis demonstrated that in intact cells, sulphonylureas inhibit channel activity by interaction with a single high-affinity site, but in inside out patches they interact with both high-affinity and low-affinity sites [81]. In excised patches, saturation of the high-affinity site produces only about $60 \%$ block of the current, whereas it appears to completely block the current in the intact cell. This anomaly arises because the extent of sulphonylurea inhibi-

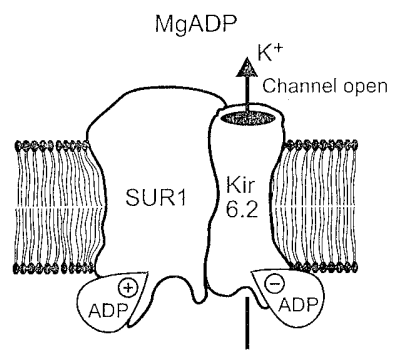

A

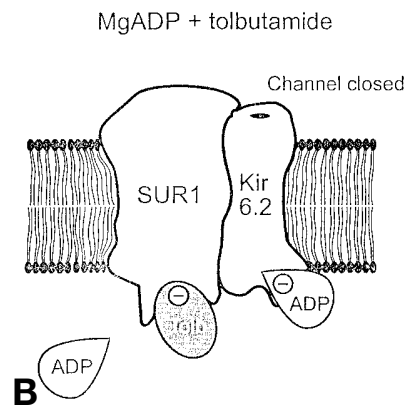

Fig. 7A, B. Model for how MgADP causes an apparent enhancement of sulphonylurea block of the beta-cell $\mathrm{K}_{\mathrm{ATP}}$ channel. In the absence of sulphonylureas (A), MgADP interacts with Kir6.2 to cause channel inhibition and with SUR1 to potentiate channel activity: the resulting current is a balance between these two opposing effects. Tolbutamide prevents the stimulatory action of MgADP, unmasking the inhibitory effect of the nucleotide (B). In the presence of MgADP and tolbutamide, therefore, the block is the sum of the inhibitory effects of both agents and is greater than that observed when MgADP is absent

tion is modulated by MgADP, which is always present in the intact cell but not (unless deliberately added) in excised patches.

It has been known for many years that MgADP enhances the inhibitory effects of tolbutamide and meglitinide on native beta-cell $\mathrm{K}_{\mathrm{ATP}}$ channels [93, 94]. Similar findings have been observed for tolbutamide, meglitinide and glibenclamide on the cloned channel (Kir6.2/SUR1) [82]. The enhanced block does not reflect an increased binding affinity for sulphonylureas when MgADP is present: instead it results because sulphonylureas abolish the stimulatory action of MgADP mediated by SUR1, while leaving the inhibitory effect of the nucleotide on Kir6.2 intact [81]. Inhibition is thus due to the combined actions of MgADP and tolbutamide (Fig.7). Sulphonylureas might interfere with the potentiatory effects of $\mathrm{Mg}$ nucleotides either by reducing nucleotide binding or by preventing the translation of binding into channel activation. The former hypothesis is supported by the observation that glibenclamide is able to block the cooperative binding of MgATP and MgADP to SUR1 [95].

In contrast to the beta-cell channel, MgADP does not potentiate the inhibitory effect of glibenclamide on either native or cloned cardiac $\mathrm{K}_{\mathrm{ATP}}$ channels (Kir6.2/SUR2A). Instead, low concentrations of MgADP apparently antagonise the effect of the sulphonylurea $[82,85,96]$, an effect which is dependent on the presence of $\mathrm{Mg}^{2+}$ [96]. Thus in the presence of MgADP, the glibenclamide block is reduced. This explains why the sulphonylurea is far less effective on cardiac $\mathrm{K}_{\mathrm{ATP}}$ channels when measured in intact cells than in the inside-out patch. The mechanism underlying the reduced sensitivity of cardiac $\mathrm{K}_{\mathrm{ATP}}$ channels to sulphonylureas in the presence of MgADP is not 
known. Nevertheless, it has important clinical implications because it means that under physiological conditions sulphonylureas will be much less effective on cardiac $\mathrm{K}_{\text {ATP }}$ channels than on those of beta cells.

The converse effect of $\mathrm{Mg}$-nucleotides on $\left[{ }^{3} \mathrm{H}\right]$ glibenclamide binding to beta-cell membranes has received considerable attention [10]. At concentrations of $0.5-1 \mathrm{mmol} / \mathrm{l}$, both $\mathrm{Mg}$-nucleotide diphosphates and triphosphates displace glibenclamide binding [90]. This may exert an additional influence on the sulphonylurea sensitivity of the $\mathrm{K}_{\mathrm{ATP}}$ channel when measured in intact cells.

Location of the sulphonylurea binding site. Sulphonylureas block the $\mathrm{K}_{\mathrm{ATP}}$ channel regardless of whether they are applied to the inside or the outside of the membrane [97, 98]: they are also effective in cellattached membrane patches when added to the bath solution. This suggests that sulphonylureas can reach their target site by diffusion through the membrane, a view supported by the fact that the undissociated, lipid-soluble form of the sulphonylurea is the effective species [99].

Although the precise location of the sulphonylurea binding site has not been identified, there is increasing evidence that it may be located towards the inner membrane surface. This includes the observation that intracellular application of the proteolytic enzyme trypsin abolished ${ }^{3}[\mathrm{H}]$-glibenclamide binding, whereas extracellular application of trypsin was without effect [100]. In addition, some sulphonylureas are more effective, or act more rapidly, when added to the inner side of the membrane than to the outside [101]. Mutagenesis studies are also consistent with an intracellular location for the tolbutamide binding site: for example, mutation of a single serine residue (S1237) which lies within the 8th intracellular loop of SUR1 abolished high-affinity tolbutamide inhibition [102].

Because SUR1 is blocked by tolbutamide with high affinity whereas SUR2A is not, chimeras of these two subunits were used to identify regions of the protein involved in tolbutamide block [102]. It was found that high-affinity tolbutamide inhibition could be conferred on SUR2A by replacing TMs 13-16 with the corresponding region of SUR1 and conversely that high-affinity tolbutamide inhibition was abolished when the same region of SUR1 was replaced with the corresponding SUR2A sequence. Clearly, impairment of tolbutamide inhibition might reflect either a decrease in drug binding or a reduction in coupling of drug binding to channel inhibition. Since the affinity of tolbutamide is too low to enable it to be used in binding studies this issue cannot be addressed directly but additional studies favour the idea that TMs 13-16 constitute the actual binding site for tolbutamide [102].
The first piece of evidence comes from the reversibility of glibenclamide action. Although both SUR1 and SUR2A are highly sensitive to glibenclamide, the block of Kir6.2/SUR2A currents is readily reversible whereas that of Kir6.2/SUR1 currents is not. Notably, transfer of tolbutamide sensitivity to SUR2A was accompanied by irreversible glibenclamide block, whereas loss of tolbutamide sensitivity in SUR1 was associated with reversible glibenclamide inhibition. The fact that tolbutamide inhibition and the irreversibility of glibenclamide block cosegregate suggests that the chimeras alter the binding properties of the channel and supports the idea that glibenclamide interacts with two parts of the SUR1 molecule (Fig. 6).

Additional evidence that TMs 13-16 of SUR1 constitute the tolbutamide-binding site comes from $\left[{ }^{3} \mathrm{H}\right]$ glibenclamide binding studies. Although glibenclamide inhibits cloned cardiac $\mathrm{K}_{\text {ATP }}$ channels with high affinity, it has not been possible to show high-affinity $\left[{ }^{3} \mathrm{H}\right]$-glibenclamide binding to SUR2A, but only to SUR1 [11, 53, 103]. A possible reason for this anomaly is offered by the observation that glibenclamide produces reversible inhibition of Kir6.2/SUR2A currents but irreversible block of Kir6.2/SUR1 currents [82], because the drug would be expected to dissociate more readily from SUR2A when membranes containing the cloned receptors are washed during the binding protocol. This idea is supported by the finding that $\left[{ }^{3} \mathrm{H}\right]$-glibenclamide binding was reduced in those SUR1 chimeras in which tolbutamide inhibition and irreversible glibenclamide block were abolished [102].

We therefore suggest that TMS13-16 of SUR1, and serine 1237 in particular, may form (part of) the tolbutamide-binding site. The location of the benzamino-binding site is still not known, and the fact that both SUR1 and SUR2A show similar sensitivity to this drug will make its identification a more difficult task.

Endogenous ligands for the sulphonylurea receptor. The high affinity with which sulphonylureas bind to SUR1 raised the question of whether an endogenous ligand for the $\mathrm{K}_{\text {ATP }}$ channel exists that is able to mimic the inhibitory effects of sulphonylureas. The search for such an endogenous ligand led to the isolation and purification of $\alpha$-endosulphine and $\beta$-endosulphine from porcine brain, two peptides which inhibit binding of sulphonylureas to their receptor in vitro [104]. Subsequently, human $\alpha$-endosulphine was cloned [105]. It is 121 amino acids long and shows considerable sequence homology with a cyclic AMP-regulated phosphoprotein of unknown function called ARPP-19 [106,107]. $\alpha$-Endosulphine is expressed in a wide range of tissues including muscle, brain and endocrine tissues. It appears to be intracellular and not secreted, since it lacks the appropriate signal peptide. The recombinant protein displaces ${ }^{3}[\mathrm{H}]$-glibenclamide binding to beta-cell membranes with an 
$\mathrm{EC}_{50}$ of approximately $1 \mu \mathrm{mol} / \mathrm{l}$, inhibits cloned betacell $\mathrm{K}_{\mathrm{ATP}}$ currents with the same affinity and stimulates insulin secretion in the absence of glucose [105]. Its functional relevance has not yet been established.

Relevance to sulphonylurea therapy in humans. The finding that some sulphonylureas display differential sensitivity towards the beta-cell, cardiac and smooth muscle types of $\mathrm{K}_{\mathrm{ATP}}$ channel inevitably raises the question of which sulphonylureas are of greatest therapeutic value in Type II diabetes.

A key issue in this regard is whether interaction of sulphonylureas with $\mathrm{K}_{\mathrm{ATP}}$ channels in extra-pancreatic tissues has any adverse effects. This question has been widely debated [108, 109]. The largest and most recent study, the UK prospective diabetes study, examined whether the incidence of microvascular and macrovascular complications in Type II diabetic patients subjected to intensive blood-glucose control is influenced by the type of therapy [110]. It found no difference in the mortality or diabetic end points of patients treated with insulin, glibenclamide or chlorpropamide. Since glibenclamide inhibits extrapancreatic $\mathrm{K}_{\mathrm{ATP}}$ channels with high affinity while chlorpropamide (which resembles tolbutamide in structure) is likely to show greater beta-cell specificity, this result suggests that if glibenclamide has any extra-pancreatic actions they do not influence mortality rates. We suggest that there may be several reasons why this is the case. First, cardiac $\mathrm{K}_{\mathrm{ATP}}$ channels are thought to be closed under physiological conditions and to open only in response to ischaemic stress [41]: obviously, glibenclamide will have no effect when the channel is already closed. Secondly, the efficacy of sulphonylureas is influenced by the metabolic state of the cell $[82,85]$. In cardiac muscle, the metabolic inhibition that occurs during ischaemia will serve to decrease drug sensitivity. Thus, even at therapeutic concentrations the drug may not completely block ischaemic activation of $\mathrm{K}_{\mathrm{ATP}}$ channels. Thirdly, even if appreciable inhibition occurs, it may not influence cardiac mortality. Indeed, it remains unclear whether sulphonylureas are detrimental or actually beneficial in cardiac ischaemia.

In beta cells, the enhanced action of sulphonylureas in the presence of ADP $[81,93]$ suggests that the effect of the drug in vivo is not fixed but instead will vary with the metabolic state of the cell. The experimental results suggest that sulphonylureas would actually have greater activity when the metabolic rate is low, as is the case when plasma glucose is low. This might have the adverse effect of increasing insulin secretion still further during hypoglycaemia. The newer sulphonylureas and their derivatives which have short biological actions might be useful in circumventing this complication.

Whether or not sulphonylureas lose efficacy with extended use is currently a matter of some dispute
[111]. In the light of this controversy, we will not consider the matter further here except to point out that although receptor down-regulation in the face of enhanced agonist concentrations is observed for many receptors, it is unlikely to account for any decline in sulphonylurea efficacy. This is because down-regulation of SUR1 would lead to a reduction in the number of $\mathrm{K}_{\mathrm{ATP}}$ channels and thus to enhanced insulin secretion.

\section{Intracellular $K_{\text {ATP }}$ channels and sulphonylurea receptors}

Sulphonylurea receptors and sulphonylurea-sensitive $\mathrm{K}_{\text {ATP }}$ channels are not only found in the plasma membrane. They have also been reported in intracellular membranes such as those of mitochondria [112] and of the secretory granules of pancreatic acinar cells and pancreatic beta cells [113, 114]. The molecular identity of these sulphonylurea receptors and their putative pore-forming partners is still not clear. The mitochondrial $\mathrm{K}_{\mathrm{ATP}}$ channel has recently been purified and shown to consist of a $63 \mathrm{kDa}$ sulphonylurea receptor $\left(\mathrm{K}_{\mathrm{d}} 60 \mathrm{nmol} / \mathrm{l}\right.$ for glibenclamide) and a 55 $\mathrm{kDa}$ pore-forming subunit [115] but the sequences of these proteins are not yet available. A $65 \mathrm{kDa}$ lowaffinity sulphonylurea receptor $\left(\mathrm{K}_{\mathrm{d}} 6 \mu \mathrm{mol} / \mathrm{l}\right.$ for glibenclamide) has also been reported in pancreatic acinar cell zymogen granule membranes and may constitute a subunit of the $\mathrm{K}_{\mathrm{ATP}}$ channel in these membranes [116]. In beta cells, sulphonylureas have been shown to enhance insulin secretion by a direct effect on the secretory machinery [117] (although others have failed to reproduce these findings [118]). It has been argued that this ability of sulphonylureas to modulate exocytosis is mediated by interaction with sulphonylurea receptors in the secretory granule membrane which exhibit high-affinity sulphonylurea binding [114]. It is important to emphasise, however, that the closure of $\mathrm{K}_{\mathrm{ATP}}$ channels in the plasma membrane is the primary mechanism of action of sulphonylureas; any effect on exocytosis will serve to amplify secretion, but not to initiate it.

\section{Other actions of sulphonylureas}

Extra-pancreatic effects of sulphonylureas include inhibition of gluconeogenesis in hepatocytes [119] and the stimulation of glucose uptake by muscle [120] and adipose tissue [121]. The drug concentrations required to achieve these effects are considerably higher than those required to block the beta-cell $K_{\text {ATP }}$ channel. For example, insulin-stimulated glucose transport in adipocytes was enhanced by glibenclamide with a $K_{i}$ of $2 \mu \mathrm{mol} / 1$ [121], a sensitivity which is about 1000 times less than that for inhibition of 
the beta-cell $\mathrm{K}_{\mathrm{ATP}}$ channel. Furthermore, the pharmacology was not identical; meglitinide, for example, was ineffective on glucose transport and tolbutamide was almost as potent as glibenclamide $\left(K_{i}, 25 \mu \mathrm{mol} / \mathrm{l}\right)$. One possible explanation for the effects of sulphonylureas on insulin-stimulated glucose transport, therefore, is that SURs, or novel sulphonylurea receptors, are involved in insulin-dependent recruitment to the plasma membrane of vesicles containing the glucose transporter GLUT4. These extra-pancreatic actions of sulphonylureas are not thought, however, to be of clinical relevance [111, 144].

Sulphonylureas are among the world's most important herbicides and stunt plant growth by inhibiting the enzyme acetolactate synthase, which is apparently absent in animals [122]. The effects of sulphonylurea herbicides on insulin secretion have not been documented in the literature.

\section{Diseases of $\mathbf{K}_{\text {ATP }}$ channel regulation}

Persistent hyperinsulinaemic hypoglycaemia of infancy (PHHI). Persistent hyperinsulinaemic hypoglycaemia of infancy is a rare recessively inherited disorder of glucose homeostasis which is characterised by unregulated insulin secretion and profound hypoglycaemia. Both familial and sporadic forms have been identified. Familial PHHI occurs at low frequency in most of northern Europe ( $\sim 1$ in 50000) but in central Finland and Saudi Arabia the incidence can be as high as 1 in approximately 2700 live births. Affected patients present shortly after birth with severe hypoglycaemia, which is associated with sustained insulin secretion despite the low blood glucose concentration. Unless the disease is rapidly recognised and treated, the hypoglycaemia may cause irreversible brain damage. The disease is probably under-diagnosed and possibly contributes to the incidence of post-natal deaths from unknown causes.

Linkage analysis of families with PHHI indicated that the gene responsible maps to chromosome 11p14-15.1 [123]. Subsequently it was found that the genes for both $\mathrm{K}_{\mathrm{ATP}}$ channel subunits are clustered in the same region and more than 12 different mutations in SUR1, and 2 in Kir6.2 have now been reported to cause PHHI [124-128]. Mutations in SUR1 are the most common cause of the disease. These mutations occur throughout the protein. On the basis of their functional effects, we suggest that they may be grouped into two classes. Class I mutations result in the total loss of functional $\mathrm{K}_{\mathrm{ATP}}$ channel activity, even in excised membrane patches. These include the deletion of a phenylalanine at position 1388 $(\Delta F 1388)$ and a V187N mutation found in the Finnish lineage $[127,128]$. Class II mutations impair the ability of MgADP to enhance $\mathrm{K}_{\text {АTP }}$ channel activity but do not change the inhibitory effect of ATP $[38,128]$.
These mutations abolish the ability of the channel to respond to changes in metabolism and cause it to be permanently closed in the intact beta cell.

Both classes of PHHI mutations result in a lack of $\mathrm{K}_{\text {ATP }}$ channel activity in the beta cell, even at low blood glucose concentrations. This results in a continuous depolarization of the beta cell and thereby a high resting intracellular $\mathrm{Ca}^{2+}$ concentration [129], which explains the constitutive insulin secretion characteristic of PHHI patients.

An animal model of PHHI. The physiological effects of the lack of $\mathrm{K}_{\text {ATP }}$ channels have also been explored using an animal model in which the gene encoding Kir6.2 was disrupted [130]. When compared to control animals, beta cells isolated from homozygous Kir6.2 knockout mice had a more depolarized resting potential and a higher intracellular $\left[\mathrm{Ca}^{2+}\right]_{i}$ concentration at rest, consistent with their lack of functional $\mathrm{K}_{\mathrm{ATP}}$ channels. Neither glucose nor tolbutamide elicited insulin secretion. Surprisingly, despite this defect in glucoseinduced insulin secretion, Kir6.2 knockout animals showed only mild impairment of glucose tolerance and their blood glucose concentrations were not different from those of normal animals. The fact that the ability of insulin to lower blood glucose concentrations was considerably enhanced in Kir6.2 knockout animals could account for this effect. This would also be consistent with a putative role for $\mathrm{K}_{\mathrm{ATP}}$ channels in extra-pancreatic tissues, as discussed above.

Diabetes. Although the aetiology of Type II diabetes mellitus is still obscure, there is evidence that the disease is associated with defective beta-cell secretion. One possible reason for the loss of glucose sensitivity would be a failure of metabolism to cause closure of the $\mathrm{K}_{\text {ATP }}$ channel, either because of a defect in the channel itself or in its regulation. The former does not appear to be a major cause of Type II diabetes because no mutations in Kir6.2 or in SUR1 associated with Type II diabetes have been detected, despite extensive screening of several populations across different ethnic groups [131-134]. One explanation for this finding may be that such mutations are lethal. A mutation that results in decreased insulin secretion is most likely to be caused by a reduction in the ATPsensitivity of the $\mathrm{K}_{\mathrm{ATP}}$ channel, and thus to occur in Kir6.2. Since Kir6.2 serves as the pore-forming subunit in many other tissues including heart, brain and smooth muscle, mutations that lead to reduced ATPsensitivity and increased $\mathrm{K}_{\mathrm{ATP}}$ channel activity can be expected to have extra-pancreatic actions. These could have adverse effects, as exemplified by the high incidence of ventricular fibrillation observed when guinea-pig hearts are treated with the $\mathrm{K}^{+}$channel opener pinacidil [135].

It remains possible, however, that defective metabolic regulation of $\mathrm{K}_{\mathrm{ATP}}$ channels might be involved 
in the aetiology of Type II diabetes. Defective metabolic regulation of $\mathrm{K}_{\mathrm{ATP}}$ channels is actually observed in two rare types of diabetes. Maturity-onset diabetes of the young (MODY2) results from mutations in glucokinase, the enzyme which catalyses the first step in glucose metabolism (the conversion of glucose to glucose-6-phosphate) in liver and beta cells [136-138]. In French families, around $80 \%$ of all MODY patients show linkage of the disease to the glucokinase gene [139]. Maturity onset diabetes of the young Type 2 shows autosomal dominant inheritance and all patients identified to date are heterozygotes. They exhibit mild hyperglycaemia with fasting blood glucose concentrations of approximately $7 \mathrm{mmol} / \mathrm{l}$. Mice in which the glucokinase gene has been disrupted (knocked-out) specifically in the beta-cell, develop severe hyperglycaemia and die within 3 days of birth whereas heterozygous animals show symptoms resembling those of MODY2 patients [140]. Because expression of glucokinase in the liver was not affected in these knockout mice, it appears that a beta-cell defect is sufficient to explain the MODY2 phenotype. There was an almost total loss of glucose sensitivity of the beta-cell $\mathrm{K}_{\mathrm{ATP}}$ channel in homozygous mice and a reduction in heterozygotes, which results from impaired glycolytic metabolism [141]. Defective regulation of $K_{\text {ATP }}$ channels probably also accounts for the reduction in glucosestimulated insulin release in MODY2 patients.

Impaired mitochondrial metabolism can also give rise to diabetes. Maternally-inherited diabetes with deafness (MIDD) results from a mutation at position 3243 of the mitochondrial DNA, which encodes a leucine transfer RNA [142]. It seems likely that the failure of insulin secretion in MIDD patients results because glucose metabolism is impaired and fails to cause closure of the $\mathrm{K}_{\mathrm{ATP}}$ channel.

\section{Conclusions}

The $\mathrm{K}_{\text {ATP }}$ channel sits at the heart of the stimulus-secretion coupling pathway in the pancreatic beta-cell. Nutrient secretagogues, like glucose, evoke $\mathrm{K}_{\mathrm{ATP}}$ channel closure as do the sulphonylurea drugs that are used by millions of diabetic patients every day. Because the $\mathrm{K}_{\mathrm{ATP}}$ channel controls the membrane potential of the beta-cell its inhibition leads to membrane depolarization and an activation of $\mathrm{Ca}^{2+}$ influx that stimulates insulin secretion.

During the past few years, there has been rapid progress in understanding the relation between the structure and function of the $\mathrm{K}_{\mathrm{ATP}}$ channel. We now know that it consists of two subunits with distinct functions, and that different kinds of $\mathrm{K}_{\mathrm{ATP}}$ channel arise by association of different types of subunit. Although the way in which the channel is modulated by metabolism continues to remain elusive, the mo- lecular mechanism of action of sulphonylureas is beginning to be unravelled. Contrary to previous assumptions, it appears that some sulphonylureas exhibit differential sensitivity to beta cell and extrapancreatic $\mathrm{K}_{\mathrm{ATP}}$ channels. The clinical relevance of this finding is probably small but it is certain to generate some debate about the choice of sulphonylurea for diabetes therapy.

The importance of the $\mathrm{K}_{\text {ATP }}$ channel for insulin secretion is clearly exemplified by the recent findings that mutations (in either subunit) that abolish channel activity produce the persistent insulin secretion that characterises PHHI whereas defects in the metabolic regulation of the channel cause MODY2 or MIDD by enhancing channel activity and so inhibit insulin secretion. Although mutations in the $\mathrm{K}_{\text {ATP }}$ channel itself are not a major cause of Type II diabetes, a question that remains largely unexplored is to what extent impaired beta-cell metabolism, and consequent defective regulation of $\mathrm{K}_{\mathrm{ATP}}$ channel activity, is involved in the aetiology of the disease.

Acknowledgements. We thank the other members of our group for helpful comments. Work in our laboratory is supported by the Wellcome Trust and the British Diabetic Association.

\section{References}

1. Janbon M, Chaptal J, Vedel A, Schaap J (1942) Accidents hypoglycémiques graves par un sulfamidothiodiazol (le VK 57 ou 2254 RP). Montpellier Med 21-22: 441-444

2. Loubatières A, Goldstein L, Metropolitanski J, Schaap J (1942) Etude expérimentale chez le chien des accidents nerveux irréversibles consécutifs a l'hypoglycémic prolongée provoqué par le sulfa-isopropylthiodiazol. 43ème Congrés des Médecins aliénistes et neurologistes de France et des pays de langue française, Montpellier. Massin, Paris, p 415

3. Franke H, Fuchs J (1955) Ein neues antidiabetisches Prinzip. Dtsch Med Wochenschr. 80: 1449-1452

4. Henquin JC (1992) The fiftieth anniversary of hypoglycaemic sulphonylureas. How did the mother compound work? Diabetologia 35: 907-912

5. Dean PM, Mathews EK (1968) Electrical activity in pancreatic islet cells. Nature 219:389-390

6. Henquin JC (1980) Tolbutamide stimulation and inhibition of insulin release: studies of the underlying ionic mechanisms in isolated rat islets. Diabetologia 18: 151-160

7. Sturgess NC, Ashford MLJ, Cook DL, Hales CN (1985) The sulphonylurea receptor may be an ATP-sensitive potassium channel. Lancet 31: 474-475

8. Ashcroft FM, Rorsman P (1989) Electrophysiology of the pancreatic $\beta$-cell. Prog Biophys Mol Biol 54: 87-143

9. Geisen K, Hitzel V, Okomonopoulos R, Pünter J, Weyer $\mathrm{R}$, Summ HD (1985) Inhibition of ${ }^{3} \mathrm{H}$-glibenclamide binding to sulfonylurea receptors by oral antidiabetics. Arzneimittelforschung 35: 707-712

10. Ashcroft FM, Ashcroft SJH (1992) The sulphonylurea receptor. Biochim Biophys Acta 1175: 45-59

11. Aguilar-Bryan L, Nichols CG, Wechsler SW et al. (1995) Cloning of the $\beta$-cell high-affinity sulphonylurea receptor: a regulator of insulin secretion. Science 268: 423-425 
12. Inagaki N, Gonoi T, Clement IV JP et al. (1995) Reconstitution of $\mathrm{I}_{\text {KATP: }}$ an inward rectifier subunit plus the sulphonylurea receptor. Science 270: 1166-1169

13. Sakura H, Ämmälä C, Smith PA, Gribble FM, Ashcroft FM (1995) Cloning and functional expression of the cDNA encoding a novel ATP-sensitive potassium channel expressed in pancreatic $\beta$-cells, brain, heart and skeletal muscle. FEBS Lett 377: 338-344

14. Edwards G, Weston AH (1993) The pharmacology of ATP-sensitive potassium channels. Annu Rev Pharmacol Toxicol 33: 597-637

15. Cook DL, Hales CN (1984) Intracellular ATP directly blocks $\mathrm{K}^{+}$channels in pancreatic $\beta$-cells. Nature 311: 271-273

16. Rorsman P, Trube G (1985) Glucose-dependent $\mathrm{K}^{+}$currents in pancreatic $\beta$-cells are regulated by intracellular ATP. Pflügers Arch 405: 305-309

17. Niki I, Ashcroft FM, Ashcroft SJH (1989) The dependence on intracellular ATP concentration of ATP-sensitive K-channels and of Na-K-ATPase in intact HIT-T15 $\beta$-cells. FEBS Lett 257: 361-364

18. Schmid-Antomarchi H, De Weille J, Fosset M, Lazdunski M (1987) The receptor for antidiabetic sulfonylureas controls the activity of the ATP-modulated $\mathrm{K}^{+}$channel in insulin-secreting cells. J Biol Chem 262: 1530-15344

19. Ashcroft FM, Harrison DE, Ashcroft SJH (1984) Glucose induces closure of single potassium channels in isolated rat pancreatic $\beta$-cells. Nature 312: 446-448

20. Ashcroft SJH, Weerasinghe LCC, Randle PJ (1973) Interelationship of islet metabolism, adenosine triphosphate content and insulin release. Biochem J 132: 223-231

21. Erecinska M, Bryla J, Michalik M, Meglasson MD, Nelson D (1992) Energy metabolism in islets of Langerhans. Biochim Biophys Acta 1101: 273-295

22. Maechler P, Wang H, Wollheim CB (1998) Continuous monitoring of ATP levels in living insulin secreting cells expressing firefly luciferase. FEBS Lett 422: 328-332

23. Kakei M, Kelly RP, Ashcroft SJH, Ashcroft FM (1986) The ATP-sensitivity of $\mathrm{K}^{+}$channels in rat pancreatic $\beta$ cells is modulated by ADP. FEBS Lett 208: 63-66

24. Dunne MJ, Petersen OH (1996) Intracellular ADP activates ATP-sensitive $\mathrm{K}^{+}$channels in an insulin-secreting cell line. FEBS Lett 208: 59-62

25. Larsson O, Deeney JT, Bränström R, Berggren P-O, Corkey BE (1996) Activation of the ATP-sensitive $\mathrm{K}^{+}$channel by long chain acyl-CoA. J Biol Chem 271: 10623-10626.

26. Branström R, Leibiger IB, Leibiger B, Corkey BE, Berggren P-O, Larsson O (1998) Long chain coenzyme A esters activate the pore-forming subunit (Kir6.2) of the ATP-regulated potassium channel. J Biol Chem 273: 31395-31400

27. Bränström R, Corkey BE, Berggren P-O, Larsson O (1997) Evidence for a unique long chain acyl-CoA ester binding site on the ATP-regulated potassium channel in mouse pancreatic $\beta$-cells. J Biol Chem 272: 17390-17394

28. Gribble FM, Proks P, Corkey BE, Ashcroft FM (1998) Mechanism of cloned $\mathrm{K}_{\mathrm{ATP}}$ channel activation by oleoylCoA. J Biol Chem 273: 26383-26387

29. Baukrowitz T, Schulte U, Oliver D et al. (1998) $\mathrm{PIP}_{2}$ and PIP as determinants for ATP-inhibition of $\mathrm{K}_{\mathrm{ATP}}$ channels. Science 282: 1141-1144

30. Shyng S-L, Nichols CG (1998) Membrane phospholipid control of nucleotide-sensitivity of $\mathrm{K}_{\mathrm{ATP}}$ channels. Science 282: 1139-1141

31. Fan Z, Makielski JC (1997) Anionic phospholipids activate ATP-sensitive potassium channels. J Biol Chem 272: 5388-5395
32. Prentki M, Corkey BE (1996) Are the $\beta$-cell signalling molecules malonyl-CoA and cytosolic long-chain acylCoA implicated in multiple tissue defects of obseity and NIDDM? Diabetes 45: 273-283

33. Prentki M, Tornheim K, Corkey BE (1997) Signal transduction mechanisms in nutrient-induced insulin secretion. Diabetologia 40:[Suppl 2] S32-S41

34. Prentki M, Vischer S, Glennon MC, Regazzi R, Deeney JT, Corkey BE (1992) Malonyl-CoA and long chain acylCoA esters as metabolic coupling factors in nutrient-induced insulin secretion. J Biol Chem 267: 5802-5810

35. Trapp S, Tucker SJ, Ashcroft FM (1997) Activation and inhibition of K-ATP currents by guanine nucleotides is mediated by different channel subunits. Proc Natl Acad Sci USA 94: 8872-8877

36. Gribble FM, Tucker SJ, Haug T, Ashcroft FM (1998) MgATP activates the $\beta$-cell $\mathrm{K}_{\mathrm{ATP}}$ channel by interaction with its SUR1 subunit. Proc Natl Acad Sci USA 95: 7185-7190

37. Gribble FM, Tucker, SJ, Ashcroft FM (1997) The essential role of the Walker A motifs of SUR1 in K-ATP channel activation by MgADP and diazoxide. EMBO J 16: 1145-1152

38. Nichols CG, Shyng SL, Nestorowicz A et al. (1996) Adenosine diphosphate as an intracellular regulator of insulin secretion. Science 272: 1785-1787

39. Shyng S-L, Ferrigni T, Nichols CG (1997) Regulation of $\mathrm{K}_{\text {ATP }}$ channel activity by diazoxide and MgADP. J Gen Physiol 110: 643-654

40. Noma A, (1983) ATP-regulated $\mathrm{K}^{+}$channels in cardiac muscle. Nature 305: 147-148

41. Nichols CG, Lederer WJ (1991) Adenosine triphosphatesensitive potassium channels in the cardiovascular system. Am J Physiol 261: H1675-H1686

42. Quayle JM, Nelson MT, Standen NB (1997) ATP-sensitive and inwardly-rectifying potassium channels in smooth muscle. Physiol Rev 77: 1165-1232

43. Davis NW, Standen NB, Stanfield PR (1991) ATP-dependent potassium channels of muscle cells: their properties, regulation, and possible functions. J Bioenerg Biomembr 23: $509-35$

44. Schmid-Antomarchi H, Amoroso S, Fosset M, Lazdunski M (1990) $\mathrm{K}^{+}$channel openers activate brain sulphonylurea-sensitive $\mathrm{K}^{+}$channels and block neurosecretion. Proc Natl Acad Sci USA 87: 3489-3492

45. Heurteax C, Bertaina V, Widmann C, Lazdunski M (1993) $\mathrm{K}^{+}$channel openers prevent global ischemia-induced expression of c-fos, c-jun, heat shock protein and amyloid $\beta$-protien precursor genes and neuronal death in rat hippocampus. Proc Natl Acad Sci USA 90: 9431-9435

46. Garrino MG, Plant TD, Henquin JC (1989) Effects of putative activators of $\mathrm{K}^{+}$channels in mouse pancreatic $\beta$ cells. Br J Pharmacol 98: 957-965

47. Faivre J-F, Findlay I (1989) Effects of tolbutamide, glibenclamide and diazoxide upon action potentials recorded from rat ventricular muscle. Biochim Biophys Acta 984: $1-5$

48. Barrett-Jolley R, McPherson GA (1998) Characterization of $\mathrm{K}_{\mathrm{ATP}}$ channels in intact mammalian skeletal muscle fibres. Br J Pharmacol 123: 1103-1110

49. Clement IV JP, Kunjilwar K, Gonzalez G et al. (1997) Association and stoichiometry of $\mathrm{K}_{\mathrm{ATP}}$ channel subunits. Neuron 18: 827-838

50. Inagaki N, Gonoi T, Seino S (1997) Subunit stoichiometry of the pancreatic $\beta$-cell ATP-sensitive $\mathrm{K}^{+}$channel. FEBS Lett 409: 232-236

51. Shyng S-L, Nichols CG (1997) Octameric stochiometry of the $\mathrm{K}_{\mathrm{ATP}}$ channel complex. J Gen Physiol 110: 655-664 
52. Inagaki N, Tsuura Y, Namba $\mathrm{N}$ et al. (1995) Cloning and functional characterization of a novel ATP-sensitive potassium channel ubiquitously expressed in rat tissues, including pancreatic islets, pituitary, skeletal muscle, and heart. J Biol Chem 270: 5691-5694

53. Isomoto S, Kondo C, Yamada M et al. (1996) A novel sulphonylurea receptor forms with BIR (Kir6.2) a smooth muscle type of ATP-sensitive $\mathrm{K}^{+}$channel. J Biol Chem 271: 24321-24325

54. Inagaki N, Gonoi T, Clement IV JP et al. (1996) A family of sulfonylurea receptors determines the properties of ATP-sensitive $\mathrm{K}^{+}$channels. Neuron 16: 1011-1017

55. Chutkow WA, Simon MC, Le Beau MM, Burant CF (1996) Cloning, tissue expression, and chromosomal localization of SUR2, the putative drug-binding subunit of cardiac, skeletal muscle, and vascular KATP channels. Diabetes 45: 1439-1445

56. Gribble FM, Ashfield R, Ämmälä C, Ashcroft FM (1997) Properties of cloned ATP-sensitive K-currents expressed in Xenopus oocytes. J Physiol (Lond) 498.1: 87-98

57. Doupnik CA, Davidson N, Lester HA (1995) The inward rectifier potassium channel family. Curr Opin Cell Biol 5: 268-278

58. Tucker SJ, Gribble FM, Zhao C, Trapp S, Ashcroft FM (1997) Truncation of Kir6.2 produces ATP-sensitive Kchannels in the absence of the sulphonylurea receptor. Nature 387: 179-81

59. Tanabe K, Tucker SJ, Matsuo M et al. (1999) Direct photoaffinity labeling of the Kir6.2 subunit of the ATPsensitive $\mathrm{K}^{+}$channel by 8-Azido-ATP. J Biol Chem 274: 3931-3933

60. Higgins C (1992) ABC transporters: from microorganisms to man. Ann Rev Cell Biol 8: 67-113

61. Higgins $\mathrm{C}$ (1995) The ABC of channel regulation. Cell 82: 693-696

62. Tusnady GE, Gakos E, Varadi A, Sarkadi B (1997) Membrane topology distinguishes a subfamily of the ATPbinding cassette (ABC) transporters. FEBS Lett 402: 1-3

63. Raab-Graham KF, Cirilo LJ, Boettcher AA, Radeke CM, Vandenberg CA (1999) Topology of the amino terminal region of the sulphonylurea receptor. Biophys J 76: A328 (Abstract)

64. Yamada M, Isomoto S, Matsumoto S et al. (1997) Suphonylurea receptor SUR2B and Kir6.1 form a sulphonylurea-sensitive but ATP-insensitive $\mathrm{K}^{+}$channel. J Physiol (Lond) 499.3: 715-720

65. Liss B, Bruns R, Röper J (1999) Alternative sulphonylurea receptor expression defines metabolic sensitivity of $\mathrm{K}$-ATP channels in dopamineric midbrain neurones. EMBO J 18: 833-846

66. Karschin A, Brockhaus J, Ballanyi K (1998) $\mathrm{K}_{\text {ATP }}$ channel formation by SUR1 receptors with Kir6.2 receptors in dorsal vagal neurones in situ. J Physiol 509: 339-346

67. Zerangue N, Schwappach B, Jan Y, Jan L (1999) A new ER trafficking signal regulates the subunit stoichiometry of plasma membrane $\mathrm{K}_{\mathrm{ATP}}$ channels. Neuron 22: 537-548

68. Ashcroft FM, Gribble FM (1998) Correlating structure and function in ATP-sensitive $\mathrm{K}+$ channels. Trends Neurosci 21: 288-294

69. Shyng S-L, Ferrigni T, Nichols CG (1997) Control of rectification and gating of cloned $\mathrm{K}_{\mathrm{ATP}}$ channels by the Kir6.2 subunit. J Gen Physiol 110: 141-153

70. John SA, Monck JR, Weiss JN, Ribalet B (1998) The sulphonylurea receptor SUR1 regulates ATP-sensitive mouse Kir6.2 $\mathrm{K}^{+}$channels linked to the green fluorescent protein in human embryonic kidney cells (HEK 293) J Physiol 510: 333-345
71. Tucker SJ, Gribble FM, Proks P et al. (1998) Molecular determinants of $\mathrm{K}_{\mathrm{ATP}}$ channel inhibition by ATP. EMBO J 17: 3290-3296

72. Trapp S, Proks P, Tucker SJ, Ashcroft FM (1998) Molecular analysis of $\mathrm{K}_{\mathrm{ATP}}$ channel gating and implications for channel inhibition by ATP. J Gen Physiol 112: 333-349

73. Drain P, Li L., Wang J (1998) $\mathrm{K}_{\text {ATP }}$ channel inhibition by ATP requires distinct functional domains of the cytoplasmic $\mathrm{C}$ terminus of the pore-forming subunit. Proc Natl Acad Sci USA 95: 13953-13958

74. Gribble FM, Tucker SJ, Haug T, Ashcroft FM (1998) MgATP activates the $\beta$-cell $\mathrm{K}_{\mathrm{ATP}}$ channel by interaction with its SUR1 subunit. Proc Natl Acad Sci USA 95: $7185-7190$

75. Senior AE, Gadsby DC (1997) ATP hydrolysis cycles and mechanism in P-glycoprotein and CFTR. Seminars in Cancer Biol 8: 143-150

76. Bokvist K, Ämmälä C, Ashcroft FM, Berggren PO, Larsson O, Rorsman P (1991) Separate processes mediate nucleotide-induced inhibition and stimulation of the ATPregulated $\mathrm{K}^{+}$channels in mouse pancreatic $\beta$-cells. Proc R Soc Lond B Biol Sci 243: 139-144

77. Hopkins WF, Fatherazi S, Peter-Riesch B, Corkey BE, Cook DL (1992) Two sites for adenine-nucleotide regulation of ATP-sensitive potassium channels in mouse pancreatic $\beta$-cells and HIT cells. J Memb Biol 129: 287-295

78. Garrino MG, Schmeer W, Nenquin M, Meissner HP, Henquin JC (1985) Mechanism of the stimulation of insulin release in vitro by HB699, a benzoic acid derivative similar to the non-sulphonylurea moiety of glibenclamide. Diabetologia 28: 697-703

79. Schwanstecher C, Meyer M, Schwanstecher M, Panten U (1998) Interaction of N-benzoyl-D-phenylalanine and related compounds with the sulphonylurea receptor of $\beta$ cell. Br J Pharmacol 123: 1023-1030

80. Akiyoshi M, Kakei M, Nakazaki M, Tanaka H (1995) A new hypoglycaemic agent, A1466, inhbits ATP-sensitive potassium channels in rat pancreatic $\beta$-cells. Am J Physiol 268: E185-E193

81. Gribble FM, Tucker SJ, Ashcroft FM (1997) The interaction of nucleotides with the tolbutamide block of K-ATP currents: a reinterpretation. J Physiol (Lond) 504. 1: $35-45$

82. Gribble FM, Tucker SJ, Seino S, Ashcroft FM (1998) Tissue specificity of sulphonylureas: studies on cloned cardiac and $\beta$-cell $\mathrm{K}_{\mathrm{ATP}}$ channels. Diabetes 47: 1412-1418

83. Sator G, Melander A, Scherstén B, Wåhlin-Boll E (1980) Influence of food and age on the single-dose kinetics and effects of tolbutamide and chlorpropamide. Eur J Clin Pharmacol 17: 285-293

84. Sator G, Melander A, Scherstén B, Wåhlin-Boll E (1980) Serum glibenclamide in diabetic patients, and influence of food on the kinetics and effects of glibenclamide. Diabetologia 18: 17-22

85. Venkatesh N, Lamp ST, Weiss JN (1991) Sulfonylureas, ATP-sensitive $\mathrm{K}^{+}$channels and cellular $\mathrm{K}^{+}$loss during hypoxia, ischemia and metabolic inhibition in mammalian ventricle. Circ Res 69: 623-637

86. Gribble FM, Ashcroft FM (1999) Differential sensitivity of $\beta$-cell and extrapancreatic $\mathrm{K}_{\mathrm{ATP}}$ channels to gliclazide. Diabetologia 42: 845-848

87. Zünckler BJ, Lenzen S, Männer K, Panten U, Trube G (1988) Concentration-dependent effects of tolbutamide, meglitinide, glipizide, glibenclamide and diazoxide on ATP-regulated $\mathrm{K}^{+}$currents in pancreatic B-cells. Naunyn-Schmiedebergs Arch Pharmacol 337: 225-230 
88. Findlay I (1992) Inhibition of ATP-sensitive $\mathrm{K}^{+}$channels in cardiac muscle by the sulphonylurea drug glibenclamlide. J Pharm Exp Ther 261: 540-545

89. Krause E, Englert H, Gogelein H (1995) Adenosine triphosphate-dependent $\mathrm{K}$ currents activated by metabolic inhibition in rat ventricular myocytes differ from those elicited by the channel opener rilmakalim. Pflugers Arch $429,625-635$

90. Schwanstecher M, Behrends S, Brandt C, Panten U (1992) The binding properties of the solubilised sulphonylurea receptor from a pancreatic $\beta$-cell line are modulated by the $\mathrm{Mg}^{++}$complex of ATP. J Pharmacol Exp Ther 262: 495-502

91. Rufer C, Losert W (1974) Blood glucose lowering sulfonamides with asymetric carbon atoms. Related N-substituted carbamoylbenzoic acids. J Med Chem 22, 750-752

92. Garrino M-G, Meissner H-P, Henquin J-C (1986) The non-sulfonylurea moiety of gliquidone mimics the effects of the parent molecule on pancreatic B-cells. Eur J Pharmacol. 124: 309-316

93. Zünkler BJ, Lins S, Ohno-Shosaku T, Trube G, Panten U (1988) Cytosolic ADP enhances the sensitivity of tolbutamide of ATP-dependent $\mathrm{K}^{+}$channels from pancreatic $\beta$ cells. FEBS Lett 239: 241-244

94. Schwanstecher C, Dickel C, Panten U (1992) Cytosolic nucleotides enhance the tolbutamide sensitivity of the ATP-dependent $\mathrm{K}$-channel in mouse pancreatic $\beta$-cells by their combined actions at inhibitory and stimulatory sites. Mol Pharmacol. 41: 480-486

95. Ueda K, Komine J, Matsuo M, Seino S, Amachi T (1999) Cooperative binding of ATP and MgADP in the sulphonylurea receptor is modulated by glibenclamide. Proc Natl Acad Sci USA 96: 1268-1272

96. Ripoll C, Lederer WJ, Nichols CG (1993) On the mechanism of inhibition of $\mathrm{K}_{\mathrm{ATP}}$ channels by glibenclamide in rat ventricular myocytes. J Cardiovasc Electrophysiol 4: $38-47$

97. Trube G, Rorsman P, Ohno-Shosaku T (1986) Opposite effects of tolbutamide and diazoxide on ATP-dependent $\mathrm{K}^{+}$-channel in pancreatic $\beta$-cells. Pflügers Arch 407: 493-499

98. Sturgess NC, Kozolowski RZ, Carrington CA, Hales CN, Ashford MLJ (1988) Effects of sulphonylureas and diazoxide on insulin secretion and nucleotide-sensitive channels in an insulin-secreting cell line. Br J Pharmacol 95: $83-84$

99. Zünckler BJ, Trube G, Panten U (1989) How do sulphonylureas approach their receptor in the B-cell plasma membrane? Naunyn-Schmiedebergs Arch Pharmacol 340: 328-332

100. Lee K, Ozanne SE, Rowe ICM, Hales CN, Ashford MLJ (1994) The effects on trypsin of ATP-regulated potassium channel properties and sulphonylurea receptors in the CRI-G1 insulin secreting cell line. Mol Pharmacol 45: 176-185

101. Schwanstecher M, Schwanstecher C, Dickel C, Chudzaik F, Moshiri A, Panten U (1994) Location of the sulphonylurea receptor at the cytoplasmic face of the $\beta$-cell membrane. Br J Pharmacol 113: 903-911

102. Ashfield R, Gribble FM, Ashcroft SJH, Ashcroft FM (1999) Identification of the high-affinity tolbutamide site on the SUR1 subunit of the KATP channel. Diabetes 48: $1341-1347$

103. Ämmälä C, Moorhouse A, Gribble F et al. (1996) Promiscuous coupling between the sulphonylurea receptor and inwardly-rectifying potassium channels. Nature 379, $545-548$
104. Virsolvy A, Brück M, Dufour M, Cauvin A, Lupo B, Bataille D (1988) An endogenous ligand for the sulphonylurea receptor. FEBS Lett 242: 65-69

105. Heron L, Virsolvy A, Gribble FM, Le Cam A, Ashcroft FM, Bataille D (1998) Cloning and functional properties of human $\alpha$-endosulfine, a putative $\mathrm{K}_{\mathrm{ATP}}$ channel regulator. Proc Natl Acad Sci USA 95: 8387-8391

106. Girault JA, Horiuchi A, Gustafson E, Rosen N, Greengard P (1990) Differential expression of ARPP-16 and ARPP-19, two highly related cAMP-regulated phosphoproteins, one of which is specifically associated with dopamine-innervated brain regions. $\mathbf{J}$ Neurosci 10: $1124-1133$

107. Horiuchi A, Williams K, Kurihara T, Nairn A, Greengard P (1990) Purification and cDNA cloning of ARPP-16, a cAMP-regulated phosphoprotein enriched in basal ganglia, and of a related phosphoprotein, ARPP-19. J Biol Chem 265: 9476-9484

108. Smits P, Thien T (1995) Cardiovascular effects of sulphonylurea derivatives. Implications for the treatment of NIDDM? Diabetologia 38: 116-122

109. Leibowitz G, Cerasi E (1996) Sulphonylurea treatment of NIDDM patients with cardiovascular disease: a mixed blessing? Diabetologia 39: 503-515

110. UKPDS (1998) Intensive blood-glucose control with sulphonylureas or insulin compared with conventional treatment and risk of complications in patients with Type II diabetes (UKPDS 33) Lancet 352: 837-853

111. Groop LC (1992) Sulphonylureas in NIDDM. Diabetes Care 15: 737-754

112. Garlid KD (1996) Cation transport in mitochondria - the potassium cycle. Biochim Biophys Acta 1275: 123-126

113. Thévenod F, Chathadi KV, Jiang B, Hopfer U (1992) ATP-sensitive $\mathrm{K}^{+}$conductance in pancreatic zymogen granules:block by glyburide and activation by diazoxide. J Memb Biol 129: 253-266

114. Ozanne SE, Guest PC, Huton JC, Hales CN (1995) Intracellular localization and molecular heterogeneity of the sulphonylurea receptor in insulin-secreting cells. Diabetologia 38: 277-282

115. Paucek P, Bajgar R, Yarov-Yarovoy V, Garlid KD (1999) Regulatory sites on mitoK $_{\text {ATP }}$ are on MitoSUR. Biophy $\mathbf{J}$ 76: A328

116. Braun M, Anderie I, Thévenod F (1997) Evidence for a 65 $\mathrm{kDa}$ sulfonylurea receptor in rat pancreatic zymogen granule membranes. FEBS Lett 411: 255-259

117. Eliasson L, Renström E, Ämmälä C, Deeney JT, Flatt PR, Gabel J, Gromada J, Larsson O, Linstrom P, Rhodes C, Rorsman P (1996) PKC-dependent stimulation of exocytosis by sulfonylureas in pancreatic $\beta$-cells. Science 271: 813-815

118. Mariot P, Gilon P, Nenquin M, Henquin JC (1998) Tolbutamide and diazoxide influence insulin secretion by changing the concentration but not the action of cytoplasmic $\mathrm{Ca}^{2+}$ in beta-cells. Diabetes 47: 365-373

119. Monge L, Mojena M, Ortega JL, Samper B, Cabello MA, Feliu-JE (1986) Chlorpropamide raises fructose-2,6 bisphosphate concentration and inhibits gluconeogenesis in isolated rat hepatocytes. Diabetes 35: 89-96

120. Wang PH, Moller D, Flier JS, Nayak RC, Smith RJ (1989) Coordinate regulation of glucose transporter function, number and gene expression by insulin and sulphonylureas in L6 rat skeletal msucle cells. J Clin Invest 84: 62-67

121. Martz A, Jo I, Jung CY (1989) Sulfonylurea binding to adipocyte membranes and potentiation of insulin-stimulated hexose transport. J Biol Chem 264: 13672-13678 
122. Wittenbach VA, Koeppe MK, Lichtner FT, Zimmerman WT, Reiser RW (1994) Basis of selectivity of triflusulfuron methyl in sugar-beets (Beta-vulgaris) Pesticid Biochem Physiol 49: 72-81

123. Thomas PM, Cote GJ, Hallman DM, Mathew PM (1995) Homozygosity mapping, to chromosome $11 \mathrm{p}$, of the gene for familial persistent hyperinsulinemic hypoglycemia of infancy. Am J Hum Genet 56: 416-421

124. Thomas PM, Cote GJ, Wohllk N et al. (1995) Mutations in the sulphonylurea receptor gene in familial persistent hyperinsulinaemic hypoglycaemia of infancy. Science 268: 425-429

125. Thomas P, Ye Y, Lightner E (1996) Mutation of the pancreatic islet inward rectifier Kir6.2 also leads to familial persistent hyperinsulinemic hypoglycemia of infancy. Hum Mol Genet 5: 1809-1812

126. Nestorowicz A, Wilson BA, Schoor KP et al. (1996) Mutations in the sulfonylurea receptor gene are associated with familial hyperinsulinism in Ashkenazi Jews. Human Mol Genet 5: 1813-1822

127. Otonkoski T, Ämmälä, C, Huopio H et al. (1998) A point mutation inactivating the sulfonylurea receptor is found in the majority of patients with persistent hyperinsulinemic hypoglycemia of infancy in Finland. Diabetes 48: 408-415

128. Shyng SL, Ferrigni T, Sheppard JB et al. (1998) Functional analyses of novel mutations in the sulfonylurea receptor 1 associated with persistent hyperinsulinaemic hypoglycaemia of infancy. Diabetes 47: 1145-1151

129. Kane C, Shepherd RM, Squires PE et al. (1996) Loss of functional $\mathrm{K}_{\mathrm{ATP}}$ channels in pancreatic $\beta$-cells causes persistent hyperinsulinemic hypoglycemia of infancy. Nature Med 2: 1344-1347

130. Miki T, Nagashima K, Tashiro F et al. (1998) Defective insulin secretion and enhanced insulin action in $\mathrm{K}_{\mathrm{ATP}}$ channel-deficient mice. Proc Natl Acad Sci USA 95: 10402-10406

131. Iwasaki N, Kawamura M, Yamagata K et al. (1996) Identification of microsatellite markers near the human genes encoding the $\beta$-cell ATP-sensitive $\mathrm{K}^{+}$channel and linkage studies in Japanese patients. Diabetes 46: 267-269

132. Sakura H, Wat N, Horton V, Millns H, Turner RC, Ashcroft FM (1996) Sequence variations in the human Kir6.2 gene, a subunit of the $\beta$-cell ATP-sensitive K-channel: no association with non-insulin dependent diabetes in white Caucasian subjects or evidence of abnormal function when expressed in vitro. Diabetologia 39: 1233-1237

133. Hani EH, Clement K, Velho G et al. (1997) Genetic studies of the sulfonylurea receptor gene locus in NIDDM and in morbid obesity among French Caucasians. Diabetes 46: 688-694

134. Inoue H, Ferrer J, Warren-Perry M et al. (1997) Sequence variants in the pancreatic islet beta-cell inwardly rectifying $\mathrm{K}^{+}$channel Kir6.2 (Bir) gene: identification and lack of role in Caucasian patients with NIDDM. Diabetes 46: 502-507

135. Padrini R, Bova S, Cargnelli G, Piovan D, Ferrari M (1992) Effects of pinacidil on guinea-pig isolated perfused heart with particular reference to the proarrhythmic effect. Br J Pharmacol 105: 715-719

136. Stoffel M, Patel P, Lo YM et al. (1992) Missense glucokinase mutation in maturity-onset diabetes of the young and mutation screening in late-onset diabetes. Nat Genet 2: $153-6$

137. Vionnet N, Stoffel M, Takeda J et al. (1992) Nonsense mutation in the glucokinase gene causes early-onset noninsulin-dependent diabetes mellitus. Nature 356: 721-722

138. Randle PJ (1993) Glucokinase and candidate gene for Type 2 (non-insulin-dependent) diabetes mellitus. Diabetologia 36: 269-275

139. Froguel P, Vaxillaire M, Sun F et al. (1992) Close linkage of glucokinase locus on chromosome $7 \mathrm{p}$ to early-onset non-insulin-dependent diabetes mellitus. Nature 356 : $162-164$

140. Terauchi Y, Sakura H, Yasuda K et al. (1995) Analysis of the pancreatic $\beta$-cell in the mouse with targeted disruption of the pancreatic beta-cell-specific glucokinase gene. J Biol Chem 270: 30253-30256

141. Sakura H, Ashcroft SJH, Terauchi Y, Kadowaki T, Ashcroft FM (1998) Glucose modulation of ATP-sensitive Kcurrents in wild-type, homozygous and heterozygous glucokinase knock-out mice. Diabetologia 41: 654-659

142. Maasen JA, Kadowaki T (1996) Maternally inherited diabetes and deafness:a new diabetes subtype. Diabetologia 39: $375-382$

143. Zünckler BJ, Henning B, Ott T, Hildebrandt AG, Fleck E (1997) Effects of tolbutamide on ATP-sensitive $\mathrm{K}^{+}$channels from human right atrial cardiac myocytes. Pharmacol Toxicol 80: 69-75

144. Panten U, Burgfeld J, Goerke F et al. (1989) Control of insulin secretion by sulfonylureas, meglitinide and diazoxide in relation to their binding to the sulfonylurea receptor in pancreatic islets. Biochem Pharmacol 38: 1217-1229

145. Takano M, Xie LH, Otani H, Horie M (1998) Cytoplasmic terminus domains of Kir6.x confer different nucleotidedependent gating on the ATP-sensitive $\mathrm{K}^{+}$channel. J Physiol 512: 395-406 